\title{
Iron sources alter the response of Southern Ocean phytoplankton to ocean acidification
}

\author{
Scarlett Trimborn ${ }^{1,2, *}$, Tina Brenneis ${ }^{1}$, Clara J. M. Hoppe ${ }^{1}$, Luis M. Laglera ${ }^{3}$, \\ Louiza Norman ${ }^{4}$, Juan Santos-Echeandía ${ }^{5}$, Christian Völkner ${ }^{1}$, \\ Dieter Wolf-Gladrow ${ }^{1}$, Christel S. Hassler ${ }^{6}$ \\ ${ }^{1}$ Alfred Wegener Institute, Helmholtz Centre for Polar and Marine Research, Bremerhaven 27570, Germany \\ ${ }^{2}$ University of Bremen, Leobener Straße NW2, Bremen 28359, Germany \\ ${ }^{3}$ FI-TRACE, University of Balearic Islands, Palma 07122, Spain \\ ${ }^{4}$ University of Cambridge, Cambridge CB2 3EA, UK \\ ${ }^{5}$ Spanish Institute of Oceanography (IEO), San Pedro del Pinatar 30740, Spain \\ ${ }^{6}$ Department F.-A. Forel, University of Geneva, Geneva 1211, Switzerland
}

\begin{abstract}
The projected rise in anthropogenic $\mathrm{CO}_{2}$ and associated ocean acidification (OA) will change trace metal solubility and speciation, potentially altering Southern Ocean (SO) phytoplankton productivity and species composition. As iron (Fe) sources are important determinants of Fe bioavailability, we assessed the effect of Fe-laden dust versus inorganic $\mathrm{Fe}\left(\mathrm{FeCl}_{3}\right)$ enrichment under ambient and high $p \mathrm{CO}_{2}$ levels (390 and $900 \mu \mathrm{atm}$ ) in a naturally Fe-limited SO phytoplankton community. Despite similar Fe chemical speciation and net particulate organic carbon (POC) production rates, $\mathrm{CO}_{2}$-dependent species shifts were controlled by Fe sources. Final phytoplankton communities of both control and dust treatments were dominated by the same species, with an OA-dependent shift from the diatom Pseudo-nitzschia prolongatoides towards the prymnesiophyte Phaeocystis antarctica. Addition of $\mathrm{FeCl}_{3}$ resulted in high abundances of Nitzschia lecointei and Chaetoceros neogracilis under ambient and high $p \mathrm{CO}_{2}$, respectively. These findings reveal that both the characterization of the phytoplankton community at the species level and the use of natural Fe sources are essential for a realistic projection of the biological carbon pump in the Felimited pelagic SO under OA. As dust deposition represents a more realistic scenario for the $\mathrm{Fe}-$ limited pelagic SO under OA, unaffected net $\mathrm{POC}$ production and dominance of $P$. antarctica can potentially weaken the export of carbon and silica in the future.
\end{abstract}

KEY WORDS: Climate change · Ocean acidification · Phytoplankton · Iron · Dust · Southern Ocean · Community composition $\cdot$ Diatoms $\cdot$ Phaeocystis

\section{INTRODUCTION}

At present, due to anthropogenic emissions, atmospheric carbon dioxide $\left(\mathrm{CO}_{2}\right)$ levels are increasing at an unprecedented rate (Hoegh-Guldberg \& Bruno 2010) and are projected to reach between 720 and $1000 \mu \mathrm{atm}$ by the end of this century (RCP6.0 scenario; IPCC 2014). The dissolution of $\mathrm{CO}_{2}$ in seawater alters its chemistry by increasing the dissolved $\mathrm{CO}_{2}$ concentration and lowering $\mathrm{pH}$ (called 'ocean acidifi-

\footnotetext{
${ }^{*}$ Corresponding author: scarlett.trimborn@awi.de
}

cation', OA). Since the beginning of the industrial revolution, the ocean has absorbed about a third of the anthropogenic $\mathrm{CO}_{2}$ emissions. Among the world oceans, the Southern Ocean (SO) sequesters a disproportionally large share of anthropogenic $\mathrm{CO}_{2}$, accounting for about $40 \%$ of the global oceanic uptake of anthropogenic $\mathrm{CO}_{2}$ (Sabine et al. 2004, Landschützer et al. 2015). However, in this region the biological sequestration potential is constrained by iron (Fe) input (Martin et al. 1990, Boyd et al. 2007,

() The authors 2017. Open Access under Creative Commons by Attribution Licence. Use, distribution and reproduction are unrestricted. Authors and original publication must be credited. 
Smetacek et al. 2012). Indeed, in situ Fe fertilization of SO surface waters relieved Fe limitation and triggered growth of predominantly diatoms (Boyd et al. 2007, Smetacek \& Naqvi 2008), accompanied by significant $\mathrm{CO}_{2}$ drawdown, and in some cases, sinking of organic matter (Blain et al. 2007, Smetacek et al. 2012). These studies, however, lack an assessment of OA impacts. Recent $\mathrm{CO}_{2}-\mathrm{Fe}$-bottle experiments with natural phytoplankton assemblages have demonstrated profound impacts on primary productivity and species shifts within the diatom assemblage with potential implications for carbon export (Tortell et al. 2008, Feng et al. 2010, Hoppe et al. 2013).

To date, SO Fe-enrichment experiments have mostly been performed using dissolved inorganic forms (Fe(III): $\mathrm{FeCl}_{3}$ and $\mathrm{Fe}(\mathrm{II})$ : $\mathrm{FeSO}_{4}$ ) (Boyd et al. 2007, Feng et al. 2010, Smetacek et al. 2012, Hoppe et al. 2013), which are considered highly bioavailable to phytoplankton (Shaked et al. 2005, Morel et al. 2008). It has been shown that most of the Fe in the ocean is bound to organic ligands (Boye et al. 2001, Boyd \& Ellwood 2010) with consequences for its bioavailability (Hutchins et al. 1999). In pelagic SO waters, upwelling is the major Fe input, resulting in enrichment of organically bound Fe (Boyd \& Ellwood 2010). Atmospheric dust deposition is another Fe source (Moore \& Braucher 2008, Boyd \& Ellwood 2010), which is known to release soluble Fe and to form colloidal Fe (Fishwick et al. 2014). Indeed, Fe associated with dust has been found to be poorly bioavailable to the $2 \mathrm{SO}$ diatoms Actinocyclus sp. and Thalassiosira (Visser et al. 2003). In line with this, the 2 SO diatoms Eucampia antarctica and Proboscia inermis were found to respond more strongly to $\mathrm{FeCl}_{3}$ than to dust enrichment, whereas Fe from dust was more bioavailable to $P$. inermis than to $E$. antarctica (Conway et al. 2016). Due to the observed species-species responses to dust and $\mathrm{FeCl}_{3}$ in the latter study, there is a need to assess their influence on natural phytoplankton assemblages of the SO. It has been suggested that Fe fertilization via dust deposition played an important role for SO biogeochemistry during glacial times, resulting in elevated primary production and carbon export, thereby decreasing atmospheric $\mathrm{CO}_{2}$ concentrations (Sigman \& Boyle 2000). In the future, some important dust-producing areas such as central Australia are predicted to become dryer (Durack et al. 2012), resulting in a change in atmospheric Fe-laden dust inputs to the SO, particularly in the context of OA.

OA will impact Fe chemistry with enhanced Fe(III) solubility in ligand-free seawater. Even though this effect may be rather small under OA (Millero et al.
2009, de Baar \& Gerringa 2009), it could change Fe(III)-ligand binding affinity, potentially causing a decline in the bioavailability of $\mathrm{Fe}$ (III) to marine phytoplankton as previously reported (Shi et al. 2010, Sugie et al. 2013). A comprehensive understanding of how concurrent changes in the partial pressure of $\mathrm{CO}_{2}\left(p \mathrm{CO}_{2}\right)$ and dust input will affect primary productivity and carbon export efficiency of SO Felimited open waters is still lacking. The aim of the present study was therefore to assess the effect of Feladen dust versus inorganic $\mathrm{Fe}\left(\mathrm{FeCl}_{3}\right)$ enrichment under present-day and future $p \mathrm{CO}_{2}$ levels (390 and 900 uatm) in a phytoplankton community of the Atlantic sector of the SO.

\section{MATERIALS AND METHODS}

\section{Experimental setup}

As Fe sources are important determinants of $\mathrm{Fe}$ bioavailability, the influence of $p \mathrm{CO}_{2}$ and different Fe sources was investigated in a naturally Fe-limited open ocean phytoplankton community (initially, dissolved Fe $[\mathrm{dFe}]=0.23 \pm 0.06 \mathrm{nmol} \mathrm{Fe} \mathrm{l}^{-1}$ ). The phytoplankton population was sampled south of the Polar Front in the Atlantic sector of the SO $\left(53^{\circ} 0.8^{\prime} \mathrm{S}\right.$, $10^{\circ} 1.5^{\prime} \mathrm{E}$ ) on 21 January 2012 during the RV 'Polarstern' expedition ANTXXVIII/3. Using a Teflon membrane pump, naturally Fe-depleted Antarctic seawater was collected from $24 \mathrm{~m}$ depth and ducted directly into a laminar flow hood inside of a tracemetal clean (TMC) van. The collection of the seawater and phytoplankton by the membrane pump was done under a pressure of $\sim 2$ bar $(2000 \mathrm{hPa})$ and led to no physical damage of the collected phytoplankton, as observed from onboard light microscopy observations. All sampling and handling of the incubations was conducted in the TMC van using TMC techniques to avoid any contamination. Tubing, bubbling systems, reservoir carboys, incubation bottles, and other equipment were acid-cleaned prior to the cruise using TMC techniques: after a 2 d Citranox detergent bath and subsequent rinsing steps with Milli-Q (MQ; Millipore), equipment was kept in acid ( $5 \mathrm{~N} \mathrm{HCl}$ for polyethylene and $1 \mathrm{~N} \mathrm{HCl}$ for polycarbonate materials) for $7 \mathrm{~d}$, followed by 7 rinses with MQ. Equipment was kept triple-bagged during storage and experiments. Polycarbonate bottles (4 l) for incubation were stored under acidified conditions (addition of $500 \mu \mathrm{l}$ of $10 \mathrm{~N}$ suprapure quartz distilled

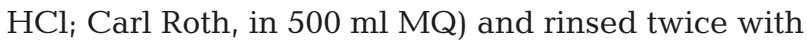
seawater prior to the start of the experiment. To 
remove any large grazers, we also filtered seawater containing the natural phytoplankton community for the incubation experiments through an acid-cleaned $200 \mu \mathrm{m}$ mesh. In addition, $200 \mathrm{l}$ seawater were filtered through TMC filter cartridges $(0.2 \mu \mathrm{m}$, AcroPak 1500; PALL) and collected for later use as dilution seawater.

All 18 polycarbonate incubation bottles (4 l) were placed into a cold room at $3 \pm 1{ }^{\circ} \mathrm{C}$ and exposed to a constant daylight irradiance of $30 \pm 5 \mu \mathrm{mol}$ photons $\mathrm{m}^{-2} \mathrm{~s}^{-1}$ (Philips Master TL-D $18 \mathrm{~W}$ daylight lamps, adjusted by neutral density screens). This irradiance level was chosen on the basis of in situ irradiance measurements at $30 \mathrm{~m}$ depth to mimic natural light conditions as close as possible and to prevent light limitation. Triplicate incubation bottles were continuously bubbled through sterile $0.2 \mu \mathrm{m}$ air filters (Midisart 2000 Sartorius stedim) with humidified air of $p \mathrm{CO}_{2}$ of 390 or 900 patm (i.e. ambient and high $p \mathrm{CO}_{2}$ treatments). $\mathrm{CO}_{2}$ gas mixtures were generated using a gas flow controller (CGM 2000; MCZ Umwelttechnik), in which $\mathrm{CO}_{2}$-free air $(<1 \mathrm{ppmv}$ $\mathrm{CO}_{2}$; Dominick Hunter) was mixed with pure $\mathrm{CO}_{2}$ (Air Liquide Germany). The $\mathrm{CO}_{2}$ concentration in the mixed gas was regularly monitored with a non-dispersive infrared analyzer system (LI6252; LI-COR Biosciences) calibrated with $\mathrm{CO}_{2}$-free air and purchased gas mixtures of $150 \pm 10$ and $1000 \pm 20 \mathrm{ppmv}$ $\mathrm{CO}_{2}$ (Air Liquide Germany). The influence of the Fe availability on the phytoplankton community was investigated by growing the incubations under natural total $\mathrm{dFe}$ concentrations of $0.23 \pm 0.06 \mathrm{nmol} \mathrm{l}^{-1}$ (e.g. control treatment) or under $\mathrm{Fe}$ enrichment of $0.5 \mathrm{nmol} \mathrm{l}^{-1}$ through either the addition of $\mathrm{FeCl}_{3}$ (ICPMS standard, TraceCERT, Fluka; i.e. $\mathrm{FeCl}_{3}$ treatment) or $0.25 \mathrm{mg} \mathrm{l}^{-1}$ Australian dust (i.e. dust treatment) originating from the Buronga region, New South Wales. The mineral dust used in this experiment was collected during a dust storm on 26 September 2009, using a high volume air sampler situated on the roof (4th floor) of the Environmental Sciences building at Griffith University, Nathan Campus, Brisbane, QLD, Australia. Prior to addition to the respective experimental bottle, the dust was dissolved in $10 \mathrm{ml} \mathrm{MQ}$ water and shaken for 2 min to homogenize the solution. Under these conditions, most of the Fe associated with the dust material used was indeed colloidal $(0.02$ to $0.2 \mu \mathrm{m})$ or particulate, releasing only $1 \%$ of Fe into the dissolved phase (C. Hassler unpubl. data). As the concentration of in situ organic ligands exceeded the $\mathrm{FeCl}_{3}$ enrichment (see Table 2), it is expected that the added Fe was buffered by naturally present ligands rather than forming inorganic colloids. Each experimental treatment was run in triplicate. To check that the $p \mathrm{CO}_{2}$ and iron manipulations were successful, in addition to the incubation bottles, Fe and carbonate chemistry was determined from abiotic control bottles, containing only filtered seawater $(0.2 \mu \mathrm{m})$, that were exposed to the same experimental treatments as the incubation bottles ( $p \mathrm{CO}_{2}$ and $\mathrm{Fe}$ availability). These abiotic control bottles confirmed the successful manipulation by addition of $\mathrm{FeCl}_{3}$ or dust, yielding similar high $\mathrm{dFe}$ concentrations irrespective of the Fe source added (see Table 1).

Initial nitrate, phosphate, and silicic acid concentrations in the collected seawater were 24.6, 1.6, and $32.1 \mu \mathrm{mol} \mathrm{l}{ }^{-1}$, respectively. No additional macronutrients were added to the incubation bottles. To monitor nutrient drawdown as an indirect indicator of phytoplankton growth, macronutrient concentrations were determined colorimetrically onboard on a regular basis ( 1 to 2 d) with a Technicon TRAACS 800 autoanalyzer following procedures improved after Grasshoff et al. (1999). When nitrate concentrations fell below $14 \mu \mathrm{mol} \mathrm{^{-1 }}$, all incubations were sampled apart from $200 \mathrm{ml}$, which were topped up with $4 \mathrm{l}$ of the initially collected filtered $(0.2 \mu \mathrm{m})$ seawater to prevent significant changes in seawater chemistry. While control treatments were diluted once, dust and $\mathrm{FeCl}_{3}$ treatments were diluted twice and freshly amended with $\mathrm{Fe}\left(\mathrm{FeCl}_{3}\right.$ or dust; see Fig. 1). The growth phases prior to and after the first dilution are denoted first and second experimental phases, respectively (see Fig. 1). In total, incubation experiments lasted between 25 and $32 \mathrm{~d}$, depending on experimental treatment.

\section{Seawater carbonate chemistry}

For the determination of seawater carbonate chemistry, samples for total alkalinity (TA), dissolved inorganic carbon (DIC) and pH were collected. TA samples were taken from the filtrate (Whatman GF/F filter, $\sim 0.6 \mu \mathrm{m}$ ), fixed with $0.03 \% \mathrm{HgCl}_{2}$, and stored in $100 \mathrm{ml}$ borosilicate flasks at $4^{\circ} \mathrm{C}$ until further analysis. TA was estimated from duplicate potentiometric titration (Brewer et al. 1986) at the Alfred Wegener Institute (Germany) using a TitroLine alpha plus (Schott Instruments) and calculated from linear Gran Plots (Gran 1952). DIC samples were gently sterilefiltered $(0.2 \mu \mathrm{m}$; Sartorius stedim), fixed with $0.03 \%$ $\mathrm{HgCl}_{2}$ and stored in $5 \mathrm{ml}$ borosilicate flasks free of air bubbles at $4^{\circ} \mathrm{C}$ until they were measured with a QuAAtro Autoanalyzer (Seal Analytical) at the home 
laboratory. Seawater pH was measured onboard using a pH/ion meter (model 713; Metrohm) that was calibrated (3-point calibration) using National Institute of Standards and Technology-certified buffer systems. Seawater carbonate chemistry (including $p \mathrm{CO}_{2}$ ) was calculated from TA and DIC, silicic acid (31 $\left.\mu \mathrm{mol} \mathrm{kg}{ }^{-1}\right)$, phosphate $\left(1.6 \mu \mathrm{mol} \mathrm{kg}{ }^{-1}\right)$, temperature $\left(3^{\circ} \mathrm{C}\right)$, and salinity (34) using CO2SYS (Pierrot et al. 2006). Equilibrium constants of Mehrbach et al. (1973) refitted by Dickson \& Millero (1987) were chosen. See Table 1 for the calculated $\mathrm{pH}_{\text {(total scale) }}$ and $p \mathrm{CO}_{2}$ values.

\section{Determination of total dFe concentrations and Fe chemical speciation}

Total dFe concentrations were determined in the initial seawater (SW), at the end of the first and second experimental phases (including the second dilution for dust and $\mathrm{FeCl}_{3}$ treatments), while Fe chemical speciation was estimated only in the initial SW and in SW samples taken at the end of the first experimental phase. Samples for dFe and Fe chemical speciation were filtered through $\mathrm{HCl}$-cleaned polycarbonate filters $(0.2 \mu \mathrm{m}$ pore size, $47 \mathrm{~mm}$; Nuclepore). While Fe speciation samples were double-bagged, frozen, and stored at $-20^{\circ} \mathrm{C}$ until further analysis, total dFe samples were determined onboard by voltammetry following the protocol described by Laglera et al. (2013). The conditional chemical speciation of Fe was determined using the competitive ligand exchange adsorptive cathodic stripping voltammetry and the ligand 2-(2-thiazolylazo)-p-cresol (TAC; $10 \mu \mathrm{mol} \mathrm{l}^{-1}$, LOT 30549; Alfa Aesar) according to Croot \& Johansson (2000). All samples were gently defrosted in the refrigerator, dispensed in $10 \mathrm{ml}$ polypropylene tubes and allowed to reach room temperature for $4 \mathrm{~h}$. Then, 4-(2-hydroxyethyl)-1-piperazinepropanesulfonic acid (EPPS; $5 \mathrm{mmol} \mathrm{l}^{-1}$ ) and increasing inorganic $\mathrm{Fe}\left(\mathrm{FeCl}_{3}, \mathrm{ICP}-\mathrm{MS}\right.$ standard; Fluka) were added to titrate the natural ligands (L) present in the SW at a fixed pH of 8.1. Following $2 \mathrm{~h}$ equilibration, TAC was added and samples were left to equilibrate overnight prior to analysis. Measurements were done with a bioanalytical system (BASi) consisting of an EC epsilon potentiostat and a controlled growth mercury electrode (CGME). The working electrode medium mercury drop (size 8) was used with the static mercury drop electrode (SMDE) instrument setting, together with an $\mathrm{Ag} / \mathrm{AgCl}$ reference electrode and a platinum wire counter electrode. An $\alpha=327$ was determined with a titration using diethylene triamine pentaacetic acid (DTPA). To determine Fe conditional chemical speciation, both the concentration of ligands (sum of ligands within our detection window, $\sum \mathrm{C}_{\mathrm{L}}$ ) and the conditional stability constants $\left(\log \mathrm{K}_{\mathrm{Fe}^{\prime} \mathrm{L}}\right)$ were calculated according to the non-linear fit method of Gerringa et al. (1995) and the linearization method van den Berg (1982). In order to also provide information on the potential bioavailable Fe forms, the concentration of Fe exchangeable after addition of $10 \mathrm{mmol}^{-1}$ of the ligand TAC to form Fe(TAC) $)_{2}$ complexes ( $\left.\mathrm{Fe}_{\text {Labile }}\right)$ and the inorganic Fe concentrations are given as well as the side-coefficient reactions for $\mathrm{Fe}^{\prime}$ and $\mathrm{Fe}^{3+}$.

\section{Chlorophyll a fluorescence}

Chlorophyll a (chl a) fluorescence was determined on a regular basis (1 to $3 \mathrm{~d}$ ) using a fluorescence induction relaxation system (FIRe; Satlantic). Samples were $1 \mathrm{~h}$ dark-acclimated prior to measurements to ensure that all photosystem II (PSII) reaction centers were fully oxidized. The duration of the dark acclimation was chosen after testing different time intervals (data not shown). Samples were then exposed to a strong short saturating flash (80 $\mu$ s single turnover flash, STF), which was applied in order to cumulatively saturate PSIIs. A relaxation period (60 $\mu$ s) of 40 weak modulated light pulses followed so that the relaxation kinetics of fluorescence yield could be recorded. Afterwards, a longer saturating pulse (20 ms multiple turnover flash, MTF) was applied in order to saturate PSII as well as the PQ (plastoquinone) pool. From this measurement, the minimum $\left(F_{\mathrm{o}}\right)$ of the STF and maximum $\left(F_{\mathrm{m}}\right)$ fluorescence of the MTF was determined. Using these 2 parameters, the maximum quantum yield of PSII $\left(F_{\mathrm{v}} / F_{\mathrm{m}}\right)$ was calculated according to the equation $\left(F_{\mathrm{m}}-F_{\mathrm{o}}\right) / F_{\mathrm{m}}$. Blank corrections at each gain setting were performed with $0.2 \mu \mathrm{m}$ filtered seawater. The photosynthetic parameters $F_{\mathrm{o}}$ and $F_{\mathrm{m}}$ were fitted using the FIRePro v.1.20 software (Satlantic). All measurements were conducted at $3^{\circ} \mathrm{C}$.

\section{Phytoplankton community characterization and biomass estimates}

To determine the taxonomic phytoplankton compositions, aliquots of $200 \mathrm{ml}$ unfiltered seawater were preserved with both hexamine-buffered formalin solution ( $2 \%$ final concentration) and Lugol (1\% final concentration) at the start of the experiment, at the 
end of the first phase (prior to the first dilution), during the second phase (prior to second dilution), and at the end of the second phase. Preserved samples were stored at $4^{\circ} \mathrm{C}$ in the dark until further analysis by inverted light microscopy (Axiovert 200; Zeiss). After transfer of $10 \mathrm{ml}$ of sample into Hydrobios sedimentation chambers, allowing settling of the cells for at least $24 \mathrm{~h}$, the dominant phytoplankton species Pseudo-nitzschia prolongatoides, Nitzschia lecointei, Chaetoceros neogracilis, Fragilariopsis curta, and Phaeocystis antarctica were enumerated at the end of the first and second experimental phase according to the method of Utermöhl (1958), following the recommendations of Edler (1979). Note that other phytoplankton species were present and counted, but represented $<5 \%$ of the total phytoplankton community and therefore were not taken into account. Each aliquot was examined until at least 400 cells had been counted in stripes. The dominating phytoplankton species were identified using scanning electron microscopy (Philips XL30) according to taxonomic literature (Tomas \& Hasle 1997). Net growth rates $(\mu)$ of the dominant phytoplankton species as well as of the whole phytoplankton community were calculated as:

$$
\mu=\left(\ln N_{t 2}-\ln N_{t 1}\right) / \Delta t
$$

where $N_{t 1}$ and $N_{t 2}$ denote the cell abundances on the respective sampling days $t_{1}$ and $t_{2}$, and $\Delta t$ is the corresponding incubation time in days. According to microscopic determination and counting, microzooplankton grazer abundance $(<200 \mu \mathrm{m})$ remained unaltered in all treatments and at all sampling times of the incubation experiment. For analysis of particulate organic carbon (POC), seawater was filtered onto pre-combusted GF/F filters $\left(15 \mathrm{~h}, 500^{\circ} \mathrm{C}\right)$ at the end of the first and second experimental phases. Filters were stored at $-20^{\circ} \mathrm{C}$ and dried for $>12 \mathrm{~h}$ at $60^{\circ} \mathrm{C}$ prior to sample preparation. Analysis was performed using an automated nitrogen carbon analyzer mass spectrometer system (ANCA-SL 20-20; SerCon). POC content was corrected for blank measurements and normalized to filtered volume. Taking into account the corresponding incubation time in days, net daily POC production rates were calculated. Samples for the determination of biogenic silica (BSi) were filtered through a cellulose acetate filter $\left(0.4 \mu \mathrm{m}_{\text {; }}\right.$ Sartorius) and stored at $-20^{\circ} \mathrm{C}$. The filters were then digested in $0.2 \mathrm{~N} \mathrm{NaOH}$ at $95^{\circ} \mathrm{C}$ for $60 \mathrm{~min}$, neutralized with $1 \mathrm{M} \mathrm{HCl}$ according to Brzezinski \& Nelson (1995), and analyzed colorimetrically for silicate using standard spectrophotometric techniques (Koroleff 1983). BSi content was normalized to filtered volume and POC content.

\section{Fe uptake}

At the end of the first and second experimental phases, Fe uptake capacities were estimated by addition of $1 \mathrm{nM}{ }^{55} \mathrm{Fe}$ (Perkin Elmer; $33.84 \mathrm{mCi} \mathrm{mg}^{-1}$ as ${ }^{55} \mathrm{FeCl}_{3}$ in $0.5 \mathrm{~N} \mathrm{HCl}$ ) to the unfiltered seawater sample after 2 to $4 \mathrm{~h}$ dark-acclimation. Generally, $2 \mathrm{ml}$ were taken from all samples to determine the initial amount of ${ }^{55} \mathrm{Fe}$. Subsequently, cells were exposed for at least $24 \mathrm{~h}$ to $30 \mu \mathrm{mol} \mathrm{m} \mathrm{m}^{-2} \mathrm{~s}^{-1}$ continuous light. At the end of the incubation time, the sample was filtered onto GF/F filters and rinsed 5 times with oxalate solution that was gravity-filtered for approx. 2 min between each rinsing step, then the filter was rinsed 3 times with natural seawater and filtered (Hassler et al. 2011). Finally, each filter was collected in a scintillation vial, amended with $10 \mathrm{ml}$ scintillation cocktail (Ultima Gold; Perkin Elmer), and mixed thoroughly (Vortex). Counts $\mathrm{min}^{-1}$ were then estimated for each sample on the shipboard scintillation counter (Tri-Carb 2900TR) and then converted into disintegrations $\mathrm{min}^{-1}$ taking into account the radioactive decay and custom quench curves. ${ }^{55} \mathrm{Fe}$ uptake was then calculated taking into account the initial ${ }^{55} \mathrm{Fe}$ concentration and the total $\mathrm{dFe}$ concentration (background and added). ${ }^{55} \mathrm{Fe}$ uptake rates were normalized to POC.

\section{Statistics}

Interactive effects of the $p \mathrm{CO}_{2}$ (390 and $\left.900 \mu \mathrm{atm}\right)$ and Fe treatments (control, dust, and $\mathrm{FeCl}_{3}$ ) on experimental parameters were statistically analyzed using 2-way ANOVA with Bonferroni's post-tests. Statistical analyses were performed using the program GraphPad Prism v.5.00 for Windows (Graph Pad Software). Significant differences were determined at the $\alpha<0.05$ level. The dissimilarity analysis of phytoplankton community composition for the different treatments was performed according to Zuur et al. (2007). A dissimilarity index (DI) of 1.00 denotes $100 \%$ dissimilarity.

\section{RESULTS}

\section{Seawater chemistry}

Initial seawater carbonate chemistry represented

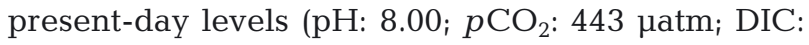
$2176 \mu \mathrm{mol} \mathrm{kg}{ }^{-1}$; TA: $2293 \mu \mathrm{mol} \mathrm{kg}{ }^{-1}$; Table 1). After sampling, all Fe treatments (control, dust, and $\mathrm{FeCl}_{3}$ ) 
Table 1. Parameters of the seawater carbonate system and total dissolved iron ( $\mathrm{dFe}$ ) concentrations. Using the CO2SYS program (Pierrot et al. 2006), $\mathrm{CO}_{2}$ and $\mathrm{pH}$ of the initial seawater (SW) and of the different treatments over the course of the experiments (before each dilution and at the end of the experiment) were calculated from total alkalinity (TA) and dissolved inorganic carbon (DIC) at $3^{\circ} \mathrm{C}$, taking into account a salinity of 34 as well as concentrations of silicic acid and phosphate of 31 and $1.6 \mu \mathrm{mol} \mathrm{kg}{ }^{-1}$, respectively. Total dFe concentrations were analyzed from filtered SW of abiotic controls as well as from the experimental bottles sampled at the end of the first and second experimental phase. Values represent the means $( \pm \mathrm{SD})$ of each respective parameter from all samplings over the course of the experiments

\begin{tabular}{|c|c|c|c|c|c|c|}
\hline Treatment & $\begin{array}{c}\text { TA } \\
\text { Experimental } \\
\text { bottles }\left(\mu \mathrm{mol} \mathrm{kg}{ }^{-1}\right)\end{array}$ & 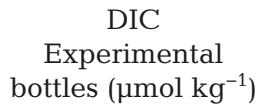 & $\begin{array}{c}\mathrm{pH} \\
\text { Experimental } \\
\text { bottles (total) }\end{array}$ & $\begin{array}{c}p \mathrm{CO}_{2} \\
\text { Experimental } \\
\text { bottles ( } \mu \mathrm{atm})\end{array}$ & $\begin{array}{c}\mathrm{dFe} \\
\text { Abiotic } \\
\text { control }\left(\mathrm{nmol} \mathrm{l}^{-1}\right)\end{array}$ & $\begin{array}{c}\mathrm{dFe} \\
\text { Experimental } \\
\text { bottles }\left(\mathrm{nmol} \mathrm{l}^{-1}\right)\end{array}$ \\
\hline Initial SW & 2293 & 2176 & 8.00 & 443 & $0.23 \pm 0.06$ & \\
\hline Control 390 & $2304 \pm 2$ & $2198 \pm 9$ & $7.97 \pm 0.02$ & $421 \pm 31$ & $0.16 \pm 0.01$ & $0.23 \pm 0.04$ \\
\hline Control 900 & $2301 \pm 4$ & $2273 \pm 4$ & $7.71 \pm 0.02$ & $914 \pm 32$ & $0.15 \pm 0.03$ & $0.21 \pm 0.02$ \\
\hline Dust 390 & $2300 \pm 5$ & $2184 \pm 5$ & $7.99 \pm 0.02$ & $434 \pm 11$ & $0.55 \pm 0.03$ & $0.28 \pm 0.16$ \\
\hline Dust 900 & $2295 \pm 16$ & $2268 \pm 4$ & $7.72 \pm 0.01$ & $889 \pm 27$ & $0.47 \pm 0.03$ & $0.23 \pm 0.06$ \\
\hline $\mathrm{FeCl}_{3} 390$ & $2309 \pm 11$ & $2182 \pm 9$ & $8.02 \pm 0.03$ & $396 \pm 39$ & $0.43 \pm 0.03$ & $0.27 \pm 0.08$ \\
\hline $\mathrm{FeCl}_{3} 900$ & $2306 \pm 4$ & $2274 \pm 7$ & $7.73 \pm 0.03$ & $873 \pm 17$ & $0.40 \pm 0.04$ & $0.23 \pm 0.06$ \\
\hline
\end{tabular}

were continuously bubbled with a $\mathrm{pCO}_{2}$ of 390 or $900 \mu \mathrm{atm}$, resulting in a stable average $\mathrm{pH}$ of $7.99 \pm$ 0.03 and $7.72 \pm 0.02$, respectively, over the course of the experiment (Table 1). Initial nitrate, phosphate, and silicic acid concentrations in the collected sea- water were $24.6,1.6$, and $32.1 \mu \mathrm{mol} \mathrm{l}^{-1}$, respectively. Throughout the experiment, concentrations of nitrate never fell below $13.2 \mu \mathrm{mol} \mathrm{l}^{-1}$ (Fig. 1d-f), while silicic acid and phosphate concentrations were always above 11.4 and $0.54 \mu_{m o l ~ ~^{-1}}$, respectively (data not

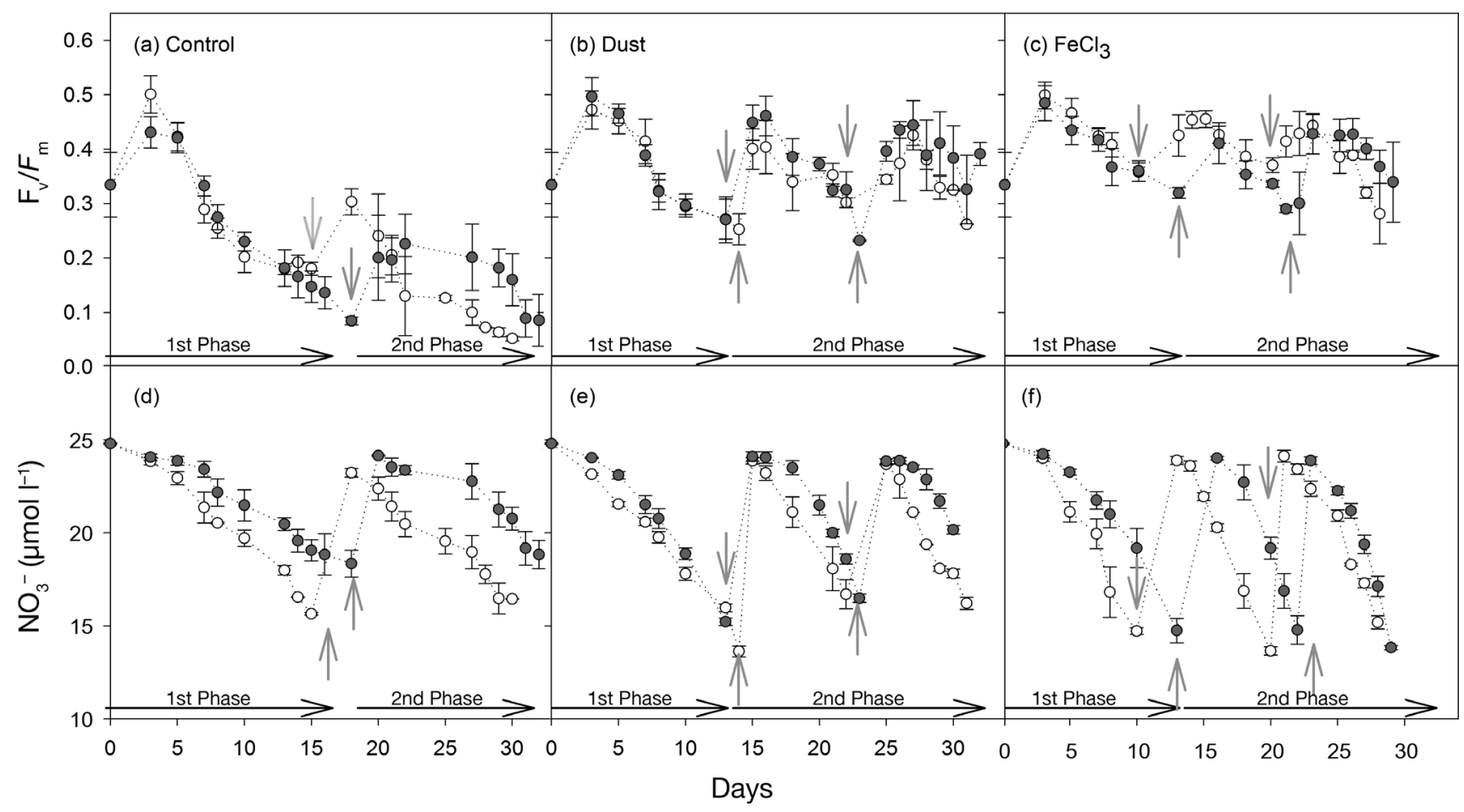

Fig. 1. Development of the maximum quantum yield of photosystem $\mathrm{II}\left(F_{\mathrm{v}} / F_{\mathrm{m}}\right)$ and $\mathrm{NO}_{3}{ }^{-}$concentrations over the course of the experiment. The dark-adapted $F_{\mathrm{v}} / F_{\mathrm{m}}$ (rel. unit) and $\mathrm{NO}_{3}{ }^{-}$concentrations $\left(\mu \mathrm{mol} \mathrm{l} \mathrm{l}^{-1}\right.$ ) are shown for $(\mathrm{a}, \mathrm{d}) \mathrm{control},(\mathrm{b}, \mathrm{e})$ dust, and (c,f) $\mathrm{FeCl}_{3}$ treatments grown at 390 (open circles) and $900 \mu \mathrm{atm} p \mathrm{CO}_{2}$ (solid circles). Values represent means ( $\pm \mathrm{SD}$ ) of triplicate incubations. Grey arrows indicate when incubations were diluted with the initially collected filtered seawater. Control treatments were diluted once while dust- and $\mathrm{FeCl}_{3}$-enriched communities were diluted twice and freshly amended with $\mathrm{Fe}$ (initial seawater enriched with dust or $\mathrm{FeCl}_{3}$ ) as indicated by the grey arrows. The growth phases before and after the first dilution are denoted the first (1st Phase) and second (2nd Phase) of the incubation experiments, respectively 
shown). Total dFe concentration in the initial seawater was $0.23 \pm 0.06 \mathrm{nmol} \mathrm{l}^{-1}$ (Table 1 ). The enrichment with dust and $\mathrm{FeCl}_{3}$ significantly increased total dFe concentrations in abiotic control bottles $(\mathrm{p}<$ 0.0001). With increasing $p \mathrm{CO}_{2}$, total $\mathrm{dFe}$ concentrations of the respective abiotic control bottles (control, dust, and $\mathrm{FeCl}_{3}$ ) remained unaltered. Over the course of the experiment, total $\mathrm{dFe}$ remained unaltered in control treatments, but was drawn down in dust and $\mathrm{FeCl}_{3}$ treatments (Table 1).

\section{Chl a fluorescence}

The $F_{\mathrm{v}} / F_{\mathrm{m}}$ of the initial phytoplankton community was $0.33 \pm 0.06$ (Fig. $1 \mathrm{a}-\mathrm{C}$ ). On Day $3, F_{\mathrm{v}} / F_{\mathrm{m}}$ values increased to $0.48 \pm 0.04$ in all treatments. On the following days, $F_{\mathrm{v}} / F_{\mathrm{m}}$ decreased to $\leq 0.2$ in all control treatments while $F_{\mathrm{v}} / F_{\mathrm{m}}$ of the dust and $\mathrm{FeCl}_{3}$ treatments did not fall below 0.2 until the end of the first experimental phase. After dilution with the initially collected filtered seawater, $F_{\mathrm{v}} / F_{\mathrm{m}}$ values increased to $\sim 0.3$ in control treatments and to $\sim 0.4$ in dust and $\mathrm{FeCl}_{3}$ treatments. Over the duration of the second experimental phase, $F_{\mathrm{v}} / F_{\mathrm{m}}$ remained $\leq 0.2$ in all control treatments whereas $F_{\mathrm{v}} / F_{\mathrm{m}}$ values did not fall below 0.2 in dust and $\mathrm{FeCl}_{3}$ treatments. Generally, dust addition resulted in similar trends in $F_{\mathrm{v}} / F_{\mathrm{m}}$ as $\mathrm{FeCl}_{3}$ enrichment. Over the course of the experiment, $F_{\mathrm{v}} / F_{\mathrm{m}}$ was significantly influenced by Fe availability $(\mathrm{p}<$ $0.0001)$, but not by $p \mathrm{CO}_{2}(\mathrm{p}>0.05)$.

\section{Fe chemical speciation}

Fe chemical speciation was determined using cathodic stripping voltammetry in the initial SW and at the end of the first experimental phase (Table 2). At the end of the first experimental phase, $\mathrm{dFe}$ had returned to its initial value among all treatments, being on average $0.22 \pm 0.05 \mathrm{nmol} \mathrm{l}^{-1}$. There was no significant trend by $\mathrm{CO}_{2}$ and/or $\mathrm{Fe}$ in concentrations of $\mathrm{Fe}_{\text {Labile }}$ and the sum of inorganic Fe forms ( $\left.\mathrm{Fe}^{\prime}\right)$, being on average $0.05 \pm 0.04 \mathrm{nmol} \mathrm{l}^{-1}$ and $0.16 \pm 0.13 \mathrm{pmol}$ $\mathrm{I}^{-1}$, respectively. Variation within the same treatment (e.g. control 390; Table 2) in concentrations of the sum of all ligands $\left(\sum \mathrm{C}_{\mathrm{L}}\right)$ and their conditional stability constants with respect to $\mathrm{Fe}^{\prime}\left(\log \mathrm{K}_{\mathrm{Fe} e^{\prime} \mathrm{L}}\right)$ prevented any statistical differences among treatments. $\Sigma \mathrm{C}_{\mathrm{L}}$ calculated according to van den Berg (1982) and Gerringa et al. (1995) were on average $0.78 \pm 0.37$ and $0.77 \pm$ $0.35 \mathrm{nmol} \mathrm{l}^{-1}$, respectively. $\log \mathrm{K}_{\mathrm{Fe} \text { 'L }}$ calculated according to van den Berg (1982) and Gerringa et al.

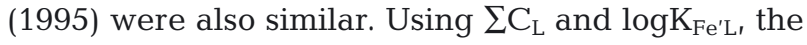
side coefficient of dissolved Fe-complex ligands $\left(\log \alpha_{\mathrm{Fe} 3+\mathrm{L}_{i}}\right.$ being $\left.\alpha_{\mathrm{Fe} 3+\mathrm{L}}=\mathrm{K} \times \mathrm{C}_{\mathrm{L}}\right)$ was calculated as an

Table 2. Fe chemical speciation determined at the end of the first experimental phase. Following Croot \& Johansson (2000), Fe chemical speciation was determined by cathodic stripping voltammetry in the initial seawater (SW) and in SW samples taken at the end of the first experimental phase. SW samples of each treatment (2 of the 3 replicates A, B, C) were measured. Using the concentrations of total dissolved $\mathrm{Fe}(\mathrm{dFe})$, concentrations of labile $\mathrm{Fe}\left(\mathrm{Fe}_{\text {Labile }}\right)$, the sum of inorganic Fe forms $(\mathrm{Fe})$, the concentration of the sum of all ligands $\left(\sum \mathrm{C}_{\mathrm{L}}\right)$ and their respective conditional stability constant with respect to $\mathrm{Fe}^{\prime}\left(\mathrm{log}_{\mathrm{Fe}} \mathrm{L}\right)$ were determined according to Gerringa et al. (1995) and van den Berg (1982). Using $\sum \mathrm{C}_{\mathrm{L}}$ and $\mathrm{K}_{\mathrm{Fe}}$, we calculated $\alpha_{\mathrm{Fe} 3+\mathrm{L}}$ as an indicator of the overall iron binding to organic ligands. For the calculations after Gerringa et al. (1995), errors on ligand concentrations and conditional stability constant were obtained using solver (Excel 2010) and the 'jackknife' procedure (Harris 1998)

\begin{tabular}{|c|c|c|c|c|c|c|c|c|}
\hline & \multirow{2}{*}{$\begin{array}{c}\mathrm{Fe}_{\text {Total }} \\
\left(\mathrm{nmol} \mathrm{l}^{-1}\right)\end{array}$} & \multirow{2}{*}{$\begin{array}{l}\mathrm{Fe}_{\text {Labile }} \\
\left(\mathrm{nmol} \mathrm{l}^{-1}\right)\end{array}$} & \multirow{2}{*}{$\begin{array}{c}\mathrm{Fe}^{\prime} \\
\left(\mathrm{pmol} \mathrm{l}^{-1}\right)\end{array}$} & \multirow[t]{2}{*}{$\log \alpha_{\mathrm{Fe} 3+\mathrm{L}}$} & \multicolumn{2}{|c|}{ Gerringa et al. (1995) } & \multicolumn{2}{|c|}{ van den Berg (1982) } \\
\hline & & & & & $\underset{\left(\mathrm{nmol} \mathrm{l}^{-1}\right)}{\sum \mathrm{C}_{\mathrm{L}}}$ & $\begin{array}{l}\sum \log K_{\mathrm{Fe}^{\prime} \mathrm{L}} \\
\left(\mathrm{nmol} \mathrm{l}^{-1}\right)\end{array}$ & $\underset{\left(\mathrm{nmol} \mathrm{l}^{-1}\right)}{\sum \mathrm{C}_{\mathrm{L}}}$ & $\begin{array}{l}\sum \log K_{\mathrm{Fe}^{\prime} \mathrm{L}} \\
\left(\mathrm{nmol} \mathrm{l}^{-1}\right)\end{array}$ \\
\hline Initial SW & 0.23 & 0.05 & 0.15 & 13.19 & $1.35 \pm 0.34$ & $12.34 \pm 0.15$ & $1.26 \pm 0.29$ & $12.43 \pm 0.22$ \\
\hline Control $390 \mathrm{~A}$ & 0.22 & 0.04 & 0.12 & 13.26 & $0.79 \pm 0.53$ & $11.26 \pm 0.24$ & $0.76 \pm 0.14$ & $11.31 \pm 0.13$ \\
\hline Control $390 \mathrm{C}$ & 0.23 & 0.17 & 0.53 & 12.64 & $0.19 \pm 0.17$ & $12.01 \pm 0.40$ & $0.18 \pm 0.05$ & $12.28 \pm 0.61$ \\
\hline Control $900 \mathrm{~A}$ & 0.20 & 0.04 & 0.12 & 13.22 & $1.30 \pm 0.09$ & $12.35 \pm 0.12$ & $1.22 \pm 0.04$ & $12.48 \pm 0.03$ \\
\hline Control 900 B & 0.20 & 0.04 & 0.12 & 13.22 & $1.24 \pm 0.05$ & $12.98 \pm 0.17$ & $1.20 \pm 0.03$ & $13.17 \pm 0.08$ \\
\hline Dust 390 A & 0.31 & 0.02 & 0.07 & 13.65 & $0.76 \pm 0.12$ & $13.31 \pm 0.98$ & $0.91 \pm 0.05$ & $12.71 \pm 0.09$ \\
\hline Dust 390 B & 0.16 & 0.03 & 0.09 & 13.26 & $0.51 \pm 0.02$ & $13.18 \pm 0.11$ & $0.52 \pm 0.02$ & $13.12 \pm 0.14$ \\
\hline Dust $900 \mathrm{~A}$ & 0.14 & 0.03 & 0.08 & 13.22 & $0.83 \pm 0.11$ & $12.82 \pm 0.10$ & $0.82 \pm 0.05$ & $12.84 \pm 0.11$ \\
\hline Dust 900 B & 0.24 & 0.03 & 0.08 & 13.49 & $1.07 \pm 0.63$ & $12.09 \pm 0.26$ & $1.01 \pm 0.20$ & $12.16 \pm 0.27$ \\
\hline $\mathrm{FeCl}_{3} 390 \mathrm{~A}$ & 0.19 & 0.02 & 0.06 & 13.50 & $0.97 \pm 0.04$ & $13.06 \pm 0.24$ & $0.95 \pm 0.03$ & $13.39 \pm 0.22$ \\
\hline $\mathrm{FeCl}_{3} 390 \mathrm{C}$ & 0.25 & 0.07 & 0.22 & 13.06 & $0.38 \pm 0.3$ & $12.59 \pm 0.08$ & $0.37 \pm 0.04$ & $12.61 \pm 0.12$ \\
\hline $\mathrm{FeCl}_{3} 900 \mathrm{~A}$ & 0.30 & 0.07 & 0.21 & 13.16 & $0.98 \pm 0.05$ & $12.45 \pm 0.07$ & $1.01 \pm 0.04$ & $12.41 \pm 0.04$ \\
\hline $\mathrm{FeCl}_{3} 900 \mathrm{C}$ & 018 & 0.07 & 0.22 & 12.92 & $0.29 \pm 0.04$ & $12.54 \pm 0.16$ & $0.29 \pm 0.07$ & $12.49 \pm 0.38$ \\
\hline
\end{tabular}


indicator of the overall Fe binding to organic ligands. In response to changes in Fe availability and $p \mathrm{CO}_{2}$, $\log \alpha_{\mathrm{Fe} 3+\mathrm{L}}$ showed a strong $\mathrm{Fe}$ complexation in all treatments, ranging between 12.64 and 13.65.

\section{Phytoplankton community characterization and biomass estimates}

As the diatoms Pseudo-nitzschia prolongatoides, Nitzschia lecointei, Chaetoceros neogracilis, and Fragilariopsis curta as well as the prymnesiophyte Phaeocystis antarctica each contributed $>5 \%$ to the community at the end of the first and second experimental phases (Fig. 2), their relative contributions are shown in Fig. 3 and Table 3. At the end of the first phase, diatoms dominated all treatments (Table 4), accounting for $62 \pm 3 \%$ up to $95 \pm 1 \%$ (Figs. $2 \& 3$, Table 3 ). Under ambient $p \mathrm{CO}_{2}, P$. prolongatoides dominated all communities ( $52 \pm 3$ to $72 \pm 3 \%$ ) while $P$. antarctica became the most abundant species in all high $p \mathrm{CO}_{2}$ treatments $(35 \pm 6$ to $39 \pm 3 \%)$. Hence, there was a significant OAdependent species shift within the phytoplankton community (control treatments: Disimilarity index (DI) $=0.89$; dust treatments: $\mathrm{DI}=0.91 ; \mathrm{FeCl}_{3}$ treatments: DI $=0.77)$. At the end of the second phase, P. prolongatoides still dominated the control and dust treatments under ambient $p \mathrm{CO}_{2}(85 \pm 6$ and $62 \pm 10 \%$, respectively), but not the $\mathrm{FeCl}_{3}$ treatments with similar carbonate chemistry. In the latter, $N$. lecointei was the most prevalent species (45 $\pm 5 \%$; Figs. $2 \& 3$, Table 3 ). In response to OA, $P$. antarctica still dominated the control and dust treatments $(57 \pm 12$ and $47 \pm 8 \%$, respectively), while $C$. neogracilis became the most

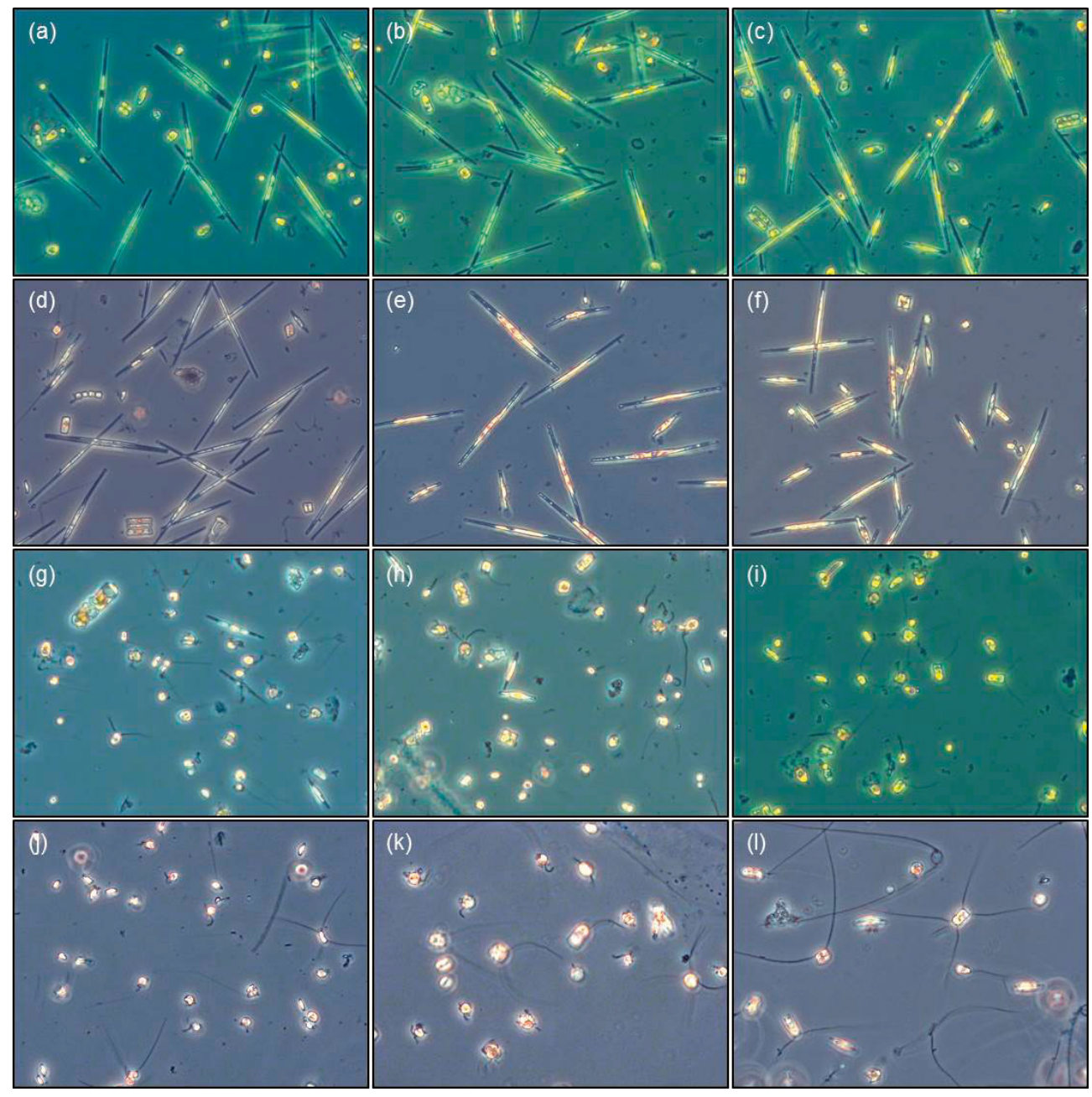

Fig. 2. Representative light microscopy pictures of phytoplankton species composition at the end of the 2 growth phases. Pictures were taken at the end of the first $(\mathrm{a}, \mathrm{b}, \mathrm{c}, \mathrm{g}, \mathrm{h}, \mathrm{i})$ and second $(\mathrm{d}, \mathrm{e}, \mathrm{f}, \mathrm{j}, \mathrm{k}, \mathrm{l})$ phases from all experimental treatments: $(\mathrm{a}, \mathrm{d}) \mathrm{control}$ 390 atm $p \mathrm{CO}_{2 i}(\mathrm{~b}, \mathrm{e})$ dust $390 \mu \mathrm{atm} p \mathrm{CO}_{2 i}(\mathrm{c}, \mathrm{f}) \mathrm{FeCl}_{3} 390 \mu \mathrm{atm} p \mathrm{CO}_{2 i}(\mathrm{~g}, \mathrm{j})$ control $900 \mu \mathrm{atm} p \mathrm{CO}_{2 i}(\mathrm{~h}, \mathrm{k})$ dust $900 \mu a$ tm $p \mathrm{CO}_{2}$; and $(\mathrm{i}, \mathrm{l}) \mathrm{FeCl}_{3} 900 \mu \mathrm{atm} p \mathrm{CO}_{2}$ 


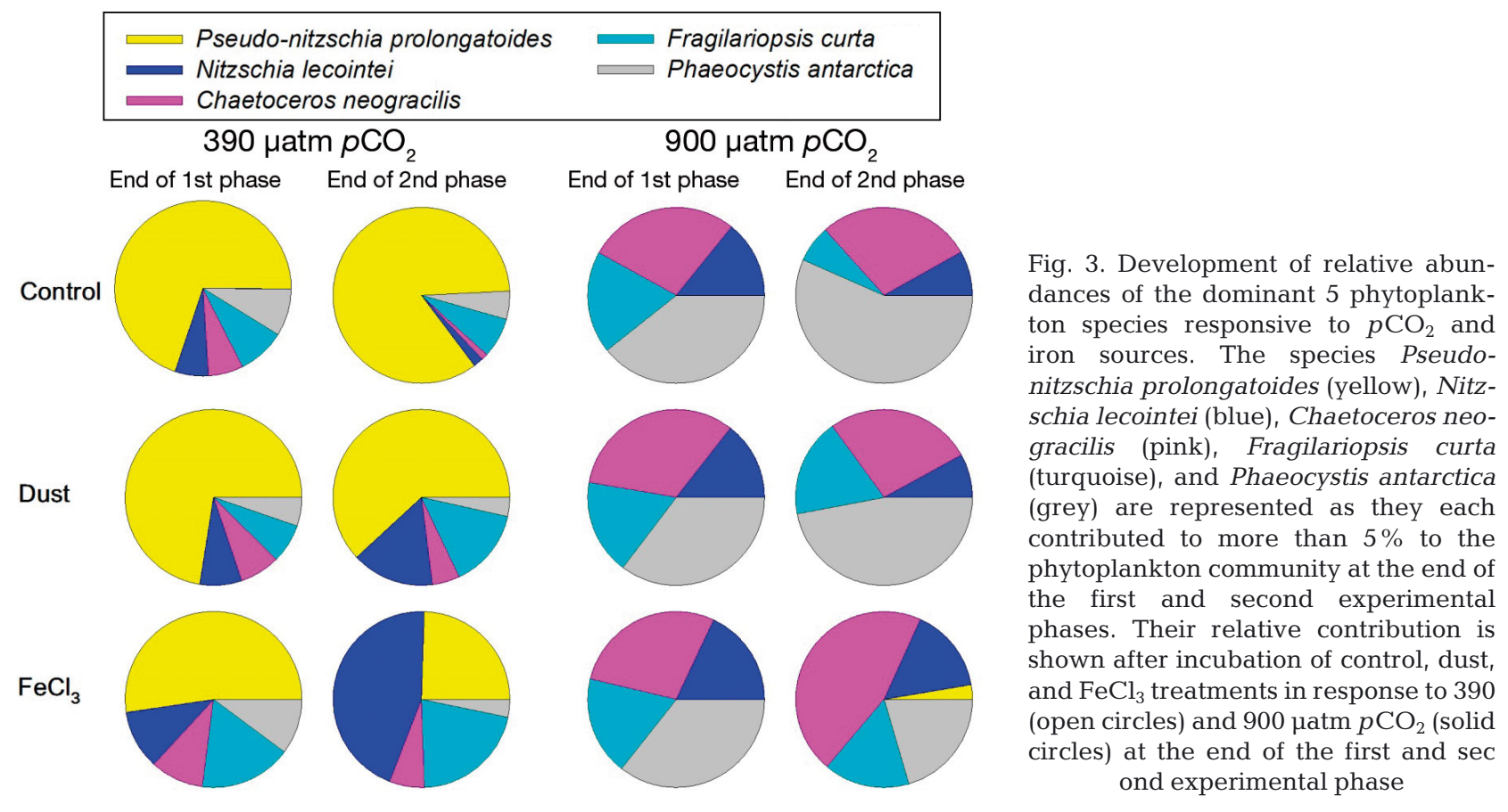

Table 3. Development of relative abundances of the dominant 5 phytoplankton species and all diatoms. Contribution of Pseudo-nitzschia prolongatoides, Nitzschia cf. lecointei, Chaetoceros neogracilis, Fragilariopsis curta, Phaeocystis antarctica and total diatoms relative to the whole phytoplankton community at the start of the experiments as well as after incubation of control, dust, and $\mathrm{FeCl}_{3}$ treatments in response to 390 and $900 \mu \mathrm{atm} p \mathrm{CO}_{2}$ at the end of the first and second experimental phase. Values represent the means $( \pm \mathrm{SD})$ of triplicate incubations

\begin{tabular}{|c|c|c|c|c|c|c|}
\hline & \multicolumn{6}{|c|}{ Relative contribution to the whole community $(\%)$} \\
\hline & $\begin{array}{l}\text { Pseudo-nitzschia } \\
\text { prolongatoides }\end{array}$ & $\begin{array}{l}\text { Nitzschia } \\
\text { lecointei }\end{array}$ & $\begin{array}{c}\text { Chaetoceros } \\
\text { neogracilis }\end{array}$ & $\begin{array}{l}\text { Fragilariopsis } \\
\text { curta }\end{array}$ & $\begin{array}{l}\text { Phaeocystis } \\
\text { antarctica }\end{array}$ & $\begin{array}{c}\text { Total } \\
\text { diatoms }\end{array}$ \\
\hline Start & 3.6 & 0.5 & 2.3 & 2.9 & 90.7 & 9.3 \\
\hline \multicolumn{7}{|c|}{ End of first phase (before first dilution) } \\
\hline Control 390 & $69.8 \pm 11.6$ & $6.1 \pm 3.1$ & $6.5 \pm 3.9$ & $8.8 \pm 2.1$ & $8.8 \pm 3.3$ & $91.2 \pm 3.3$ \\
\hline Control 900 & $0.0 \pm 0.0$ & $14.3 \pm 5.5$ & $27.7 \pm 6.5$ & $18.7 \pm 1.5$ & $39.4 \pm 2.5$ & $60.6 \pm 2.5$ \\
\hline Dust 390 & $72.5 \pm 3.2$ & $7.7 \pm 0.2$ & $7.4 \pm 3.1$ & $7.2 \pm 1.3$ & $5.3 \pm 1.0$ & $94.7 \pm 1.0$ \\
\hline Dust 900 & $0.0 \pm 0.0$ & $14.5 \pm 2.8$ & $32.8 \pm 7.8$ & $17.3 \pm 7.9$ & $35.4 \pm 5.9$ & $64.6 \pm 5.9$ \\
\hline $\mathrm{FeCl}_{3} 390$ & $52.3 \pm 3.2$ & $10.8 \pm 3.8$ & $9.8 \pm 2.4$ & $16.8 \pm 3.5$ & $10.2 \pm 3.6$ & $89.8 \pm 3.6$ \\
\hline $\mathrm{FeCl}_{3} 900$ & $0.0 \pm 0.0$ & $18.0 \pm 3.4$ & $28.2 \pm 5.9$ & $18.0 \pm 9.4$ & $35.6 \pm 15.2$ & $64.1 \pm 18.7$ \\
\hline \multicolumn{7}{|c|}{ Second phase (after first dilution) } \\
\hline \multicolumn{7}{|c|}{ Second dilution } \\
\hline Dust 390 & $74.0 \pm 1.9$ & $8.2 \pm 2.2$ & $5.0 \pm 1.5$ & $8.6 \pm 4.6$ & $4.2 \pm 1.0$ & $95.8 \pm 1.0$ \\
\hline Dust 900 & $0.0 \pm 0.0$ & $14.0 \pm 4.2$ & $29.7 \pm 8.3$ & $10.5 \pm 3.4$ & $45.8 \pm 7.6$ & $54.2 \pm 7.6$ \\
\hline $\mathrm{FeCl}_{3} 390$ & $39.1 \pm 4.3$ & $32.5 \pm 4.4$ & $9.4 \pm 1.4$ & $12.9 \pm 5.7$ & $6.5 \pm 1.6$ & $93.5 \pm 1.6$ \\
\hline $\mathrm{FeCl}_{3} 900$ & $0.0 \pm 0.0$ & $20.6 \pm 11.8$ & $29.9 \pm 1.8$ & $12.6 \pm 9.8$ & $36.9 \pm 23.4$ & $63.1 \pm 23.4$ \\
\hline \multicolumn{7}{|c|}{ End of second phase } \\
\hline Control 390 & $84.4 \pm 6.2$ & $1.8 \pm 1.0$ & $1.2 \pm 0.7$ & $7.3 \pm 2.5$ & $5.2 \pm 2.8$ & $94.8 \pm 2.8$ \\
\hline Control 900 & $0.0 \pm 0.0$ & $8.2 \pm 6.9$ & $28.4 \pm 9.3$ & $6.7 \pm 2.8$ & $56.7 \pm 12.2$ & $43.3 \pm 12.2$ \\
\hline Dust 390 & $61.5 \pm 9.6$ & $15.0 \pm 10.9$ & $5.1 \pm 2.7$ & $14.4 \pm 5.2$ & $3.5 \pm 0.9$ & $96.5 \pm 0.9$ \\
\hline Dust 900 & $0.0 \pm 0.0$ & $8.0 \pm 4.0$ & $27.0 \pm 9.2$ & $18.0 \pm 6.9$ & $47.0 \pm 7.5$ & $53.0 \pm 7.5$ \\
\hline $\mathrm{FeCl}_{3} 390$ & $24.5 \pm 2.7$ & $44.5 \pm 4.8$ & $6.4 \pm 2.8$ & $21.2 \pm 1.3$ & $3.3 \pm 0.8$ & $96.7 \pm 0.8$ \\
\hline $\mathrm{FeCl}_{3} 900$ & $2.7 \pm 0.7$ & $15.5 \pm 4.4$ & $45.6 \pm 4.0$ & $15.6 \pm 1.9$ & $20.5 \pm 0.8$ & $79.5 \pm 0.8$ \\
\hline
\end{tabular}


abundant species in $\mathrm{FeCl}_{3}$ treatments ( $46 \pm 4 \%$; Figs. 2 $\& 3$, Table 3). At both $p \mathrm{CO}_{2}$ levels, the phytoplankton community composition of control treatments was similar to that of the dust treatments (390 treatments: DI = 0.13 ; 900 treatments: DI $=0.06$ ), but significantly differed from the $\mathrm{FeCl}_{3}$ treatments (390 treatments: DI = $0.71 ; 900$ treatments: $\mathrm{DI}=0.39$ ).

At the end of the first phase, net $\mu$ of $P$. antarctica was not altered by Fe availability, but significantly increased with increasing $p \mathrm{CO}_{2}$ in all treatments $(\mathrm{p}=$ 0.0014) (Fig. 4a). In comparison, net $\mu$ of the diatom community was controlled by the availability of both $p \mathrm{CO}_{2}(\mathrm{p}<0.0001)$ and $\mathrm{Fe}(\mathrm{p}=0.0325)$ (Fig. $\left.4 \mathrm{~b}\right)$. With increasing $p \mathrm{CO}_{2}$, net $\mu$ significantly declined in all $\mathrm{Fe}$ treatments, with the control treatment exhibiting the strongest decline (post hoc: $\mathrm{p}<0.001$ ). At the end of the experiments, net $\mu$ of $P$. antarctica was significantly influenced by $\mathrm{Fe}$ availability $(\mathrm{p}<0.0001)$ as well as changes in $p \mathrm{CO}_{2}(\mathrm{p}=0.0072)$ (Fig. 4c). Under ambient $p \mathrm{CO}_{2}, \mu$ increased by $42 \%$ (post hoc: $\mathrm{p}<$ 0.05 ) and $50 \%$ (post hoc: $\mathrm{p}<0.01$ ) after addition of dust and $\mathrm{FeCl}_{3}$, respectively. Within high $p \mathrm{CO}_{2}$ treatments, only the addition of $\mathrm{FeCl}_{3}$ stimulated $\mu$ by
$19 \%$ (post hoc: $\mathrm{p}<0.05$ ). Net $\mu$ of the diatom community showed a significant effect only with Fe availability $(\mathrm{p}<0.0001)$, with a significant increase of 59 and $75 \%$ under ambient (post hoc: $\mathrm{p}<0.001$ ) and high (post hoc: $\mathrm{p}<0.0001) p \mathrm{CO}_{2}$, respectively, after enrichment with $\mathrm{FeCl}_{3}$, but not with dust (Fig. 4d).

At the end of the first phase, net daily POC production was significantly affected by Fe availability $(\mathrm{p}<$ $0.0005)$ and changes in $p \mathrm{CO}_{2}(\mathrm{p}<0.0007)$ (Table 5). At both $p \mathrm{CO}_{2}$ levels, net daily POC production significantly increased in response to addition of $\mathrm{FeCl}_{3}$ (post hoc: $\mathrm{p}<0.05$ ) and dust, but in the latter only under high $p \mathrm{CO}_{2}$ (post hoc: $\mathrm{p}<0.05$ ). In response to $\mathrm{OA}$, net POC production significantly declined in control and $\mathrm{FeCl}_{3}$ treatments (post hoc: $\mathrm{p}<0.05$ ), but not in response to dust enrichment. Final net POC production did not change in response to $p \mathrm{CO}_{2}$ or to Fe availability.

The BSi:POC ratio of the initial phytoplankton community was $0.69 \pm 0.02 \mathrm{~mol} \mathrm{~mol}^{-1}$ (Table 5). At the end of the first phase, $\mathrm{BSi}$ :POC ratios did not change in response to changes in Fe availability or $p \mathrm{CO}_{2}$. A significant OA-dependent reduction by $50 \%$ in $\mathrm{BSi}: \mathrm{POC}$ ratios of final phytoplankton communities was observed in both control and dust treatments $(\mathrm{p}<0.05)$.

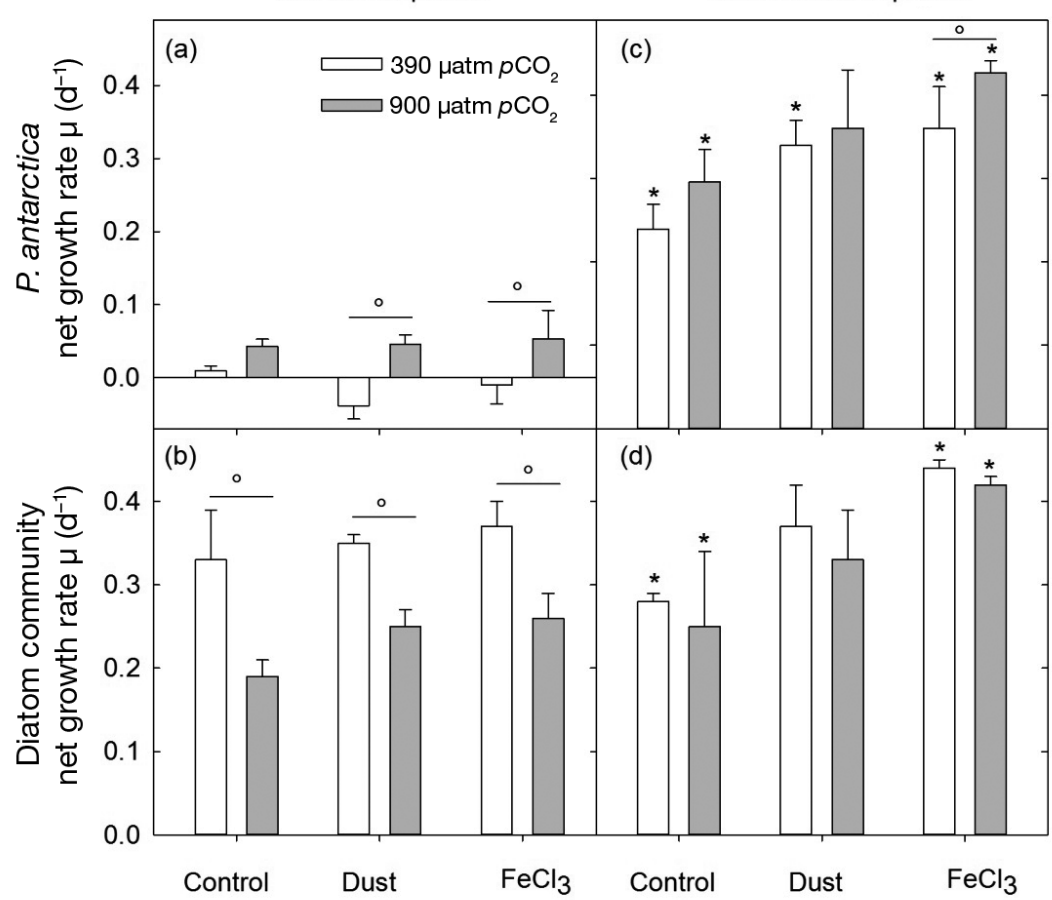

Fig. 4. Net growth rates of Phaeocystis antarctica and the total diatom community in response to $p \mathrm{CO}_{2}$ and iron sources. Net growth rates $\left(\mu_{i} \mathrm{~d}^{-1}\right)$ of $P$. antarctica and the diatom community for control, dust- and $\mathrm{FeCl}_{3}$-enriched phytoplankton communities grown at 390 (open bars) or $900 \mu \mathrm{atm} p \mathrm{CO}_{2}$ (grey bars) at the end of the $(a, b)$ first and $(c, d)$ second phase are shown. Values represent the means $( \pm \mathrm{SD})$ of triplicate incubations. Significant differences between treatments are indicated by ${ }^{*}$ for $\mathrm{Fe}$ effects and by ${ }^{\circ}$ for $\mathrm{CO}_{2}$ effects

\section{Fe uptake}

The Fe uptake:POC ratio of the initial phytoplankton community was $26.51 \pm 3.97 \mu \mathrm{mol} \mathrm{mol}{ }^{-1}$ (Table 5). At the end of the first phase, this ratio remained unaffected by changes in $\mathrm{Fe}$ availability and $p \mathrm{CO}_{2}$ (Table 5). However, at the end of the experiments, Fe uptake:POC ratios were strongly controlled by Fe availability ( $\mathrm{p}=0.001$ ) and $p \mathrm{CO}_{2}(\mathrm{p}<0.0001)$ as well as their interactive effects $(p=0.0006)$ (Table 5). Following addition of dust or $\mathrm{FeCl}_{3}, \mathrm{Fe}$ uptake:POC ratios were not altered under ambient, but under high $p \mathrm{CO}_{2}$, were reduced by $29 \%$ (post hoc: $\mathrm{p}<0.01$ ) and $52 \%$, respectively (post hoc: $\mathrm{p}<0.0001$ ). With increasing $p \mathrm{CO}_{2}$, Fe uptake:POC ratios of control and dust treatments were significantly enhanced, by $127 \%$ (post hoc: p < 0.0001 ) and $73 \%$ (post hoc: $\mathrm{p}<0.01$ ), respectively, but remained unaltered in $\mathrm{FeCl}_{3}$ treatments. 
Table 4. Development of cell abundances (cells $\mathrm{ml}^{-1}$ ) of the dominant 5 phytoplankton species and all diatoms. Cell abundances of Pseudo-nitzschia prolongatoides, Nitzschia cf. lecointei, Chaetoceros neogracilis, Fragilariopsis curta, Phaeocystis antarctica and total diatoms determined at the start of the experiments as well as after incubation of control, dust, and $\mathrm{FeCl}_{3}$ treatments in response to 390 and $900 \mu \mathrm{atm} p \mathrm{CO}_{2}$ at the end of the first and second experimental phase. Values represent the means $( \pm \mathrm{SD})$ of triplicate incubations

\begin{tabular}{|c|c|c|c|c|c|c|}
\hline \multicolumn{7}{|c|}{ Cell number (cells ml ${ }^{-1}$ ) } \\
\hline & $\begin{array}{c}\text { Pseudo-nitzschia } \\
\text { prolongatoides }\end{array}$ & $\begin{array}{l}\text { Nitzschia } \\
\text { lecointei }\end{array}$ & $\begin{array}{c}\text { Chaetoceros } \\
\text { neogracilis }\end{array}$ & $\begin{array}{c}\text { Fragilariopsis } \\
\text { curta }\end{array}$ & $\begin{array}{l}\text { Phaeocystis } \\
\text { antarctica }\end{array}$ & $\begin{array}{c}\text { Total } \\
\text { diatoms }\end{array}$ \\
\hline Start & 104 & 15 & 67 & 85 & 2660 & 271 \\
\hline \multicolumn{7}{|c|}{ End of first phase (before first dilution): } \\
\hline Control 390 & $28299 \pm 15835$ & $2118 \pm 742$ & $2200 \pm 1069$ & $3230 \pm 519$ & $3122 \pm 4188$ & $35847 \pm 15225$ \\
\hline Control 900 & $0 \pm 0$ & $2860 \pm 1751$ & $4981 \pm 2471$ & $2342 \pm 345$ & $5486 \pm 1225$ & $10183 \pm 4012$ \\
\hline Dust 390 & $22009 \pm 1685$ & $2337 \pm 229$ & $2235 \pm 922$ & $2189 \pm 521$ & $1623 \pm 427$ & $28771 \pm 1845$ \\
\hline Dust 900 & $0 \pm 0$ & $2133 \pm 599$ & $4924 \pm 1857$ & $2431 \pm 761$ & $5182 \pm 1056$ & $9488 \pm 1748$ \\
\hline $\mathrm{FeCl}_{3} 390$ & $14597 \pm 2111$ & $3075 \pm 1384$ & $2773 \pm 910$ & $4618 \pm 565$ & $2778 \pm 757$ & $25063 \pm 3646$ \\
\hline $\mathrm{FeCl}_{3} 900$ & $0 \pm 0$ & $3078 \pm 319$ & $4842 \pm 665$ & $3124 \pm 1582$ & $6318 \pm 2986$ & $11044 \pm 2161$ \\
\hline \multicolumn{7}{|c|}{ Second phase (after first dilution): } \\
\hline Dust 390 & $30304 \pm 8357$ & $3407 \pm 1368$ & $2058 \pm 731$ & $3324 \pm 1315$ & $1723 \pm 665$ & $39093 \pm 9846$ \\
\hline Dust 900 & $0 \pm 0$ & $4556 \pm 2381$ & $8572 \pm 809$ & $3042 \pm 892$ & $14457 \pm 6323$ & $16170 \pm 3590$ \\
\hline $\mathrm{FeCl}_{3} 390$ & $18299 \pm 4192$ & $15203 \pm 3875$ & $4320 \pm 101$ & $5668 \pm 1933$ & $2951 \pm 391$ & $43491 \pm 6033$ \\
\hline $\mathrm{FeCl}_{3} 900$ & $0 \pm 0$ & $6795 \pm 6041$ & $8912 \pm 4239$ & $4323 \pm 4444$ & $9407 \pm 2310$ & $20031 \pm 14723$ \\
\hline \multicolumn{7}{|c|}{ End of second phase } \\
\hline Control 390 & $61550 \pm 19232$ & $1138 \pm 494$ & $730 \pm 358$ & $5372 \pm 2815$ & $3514 \pm 1237$ & $62445 \pm 19461$ \\
\hline Control 900 & $0 \pm 0$ & $2978 \pm 3341$ & $8526 \pm 758$ & $1997 \pm 355$ & $18945 \pm 8637$ & $13501 \pm 4386$ \\
\hline Dust 390 & $17611 \pm 7295$ & $3781 \pm 2266$ & $1381 \pm 624$ & $4260 \pm 1466$ & $986 \pm 348$ & $26942 \pm 6713$ \\
\hline Dust 900 & $0 \pm 0$ & $1850 \pm 321$ & $8252 \pm 6070$ & $4583 \pm 2238$ & $12927 \pm 6096$ & $14685 \pm 8124$ \\
\hline $\mathrm{FeCl}_{3} 390$ & $10947 \pm 1446$ & $20222 \pm 5615$ & $2769 \pm 980$ & $8961 \pm 1952$ & $1331 \pm 134$ & $43598 \pm 7543$ \\
\hline $\mathrm{FeCl}_{3} 900$ & $829 \pm 518$ & $7101 \pm 2603$ & $13003 \pm 8687$ & $7018 \pm 261$ & $9264 \pm 1158$ & $35873 \pm 2720$ \\
\hline
\end{tabular}

Table 5. Net daily particulate organic carbon (POC) production, BSi:POC and Fe uptake:POC ratios. Results are shown for control, dust- and $\mathrm{FeCl}_{3}$-enriched phytoplankton communities grown at 390 or $900 \mu \mathrm{atm} p \mathrm{CO}_{2}$ that were sampled at the end of the first and second experimental phase. Values represent the means $( \pm \mathrm{SD})$ of triplicate incubations. Significant differences between treatments are indicated by ${ }^{*}$ for $\mathrm{Fe}$ effects and by ${ }^{\circ}$ for $\mathrm{CO}_{2}$ effects

\begin{tabular}{|lccc|}
\hline & $\begin{array}{c}\text { Net POC } \\
\text { production } \\
\left(\mu \mathrm{g} \mathrm{C} \mathrm{d}^{-1}\right)\end{array}$ & $\begin{array}{c}\text { BSi: } \\
\text { POC } \\
\left(\mathrm{mol} \mathrm{mol}^{-1}\right)\end{array}$ & $\begin{array}{c}\text { Fe uptake: } \\
\text { POC } \\
\left(\mu \mathrm{mol} \mathrm{mol}^{-1}\right)\end{array}$ \\
\hline Start & $0.69 \pm 0.02$ & $26.51 \pm 3.97$ \\
End of first phase & & \\
Control 390 & $0.14 \pm 0.02^{* \circ}$ & $0.08 \pm 0.01$ & $6.07 \pm 1.19$ \\
Control 900 & $0.09 \pm 0.02^{* \circ}$ & $0.07 \pm 0.02$ & $6.44 \pm 1.44$ \\
Dust 390 & $0.16 \pm 0.01$ & $0.10 \pm 0.02$ & $4.17 \pm 0.94$ \\
Dust 900 & $0.14 \pm 0.02^{*}$ & $0.09 \pm 0.00$ & $6.53 \pm 1.90$ \\
FeCl $_{3} 390$ & $0.19 \pm 0.01^{* \circ}$ & $0.08 \pm 0.02$ & $4.60 \pm 0.86$ \\
FeCl $_{3} 900$ & $0.15 \pm 0.01^{\circ}$ & $0.06 \pm 0.03$ & $5.01 \pm 1.36$ \\
End of second phase & & \\
Control 390 & $0.23 \pm 0.01^{*}$ & $0.06 \pm 0.02^{\circ}$ & $6.27 \pm 2.02^{\circ}$ \\
Control $900^{\circ}$ & $0.20 \pm 0.05$ & $0.03 \pm 0.02^{\circ}$ & $14.24 \pm 0.82^{* \circ}$ \\
Dust 390 $_{\text {Dust 900 }} 0.17 \pm 0.02^{*}$ & $0.04 \pm 0.01^{\circ}$ & $5.81 \pm 0.52^{\circ}$ \\
$\mathrm{FeCl}_{3} 390$ & $0.14 \pm 0.02$ & $0.02 \pm 0.00^{\circ}$ & $10.06 \pm 1.65^{* \circ}$ \\
$\mathrm{FeCl}_{3} 900$ & $0.18 \pm 0.00$ & $0.04 \pm 0.01$ & $6.59 \pm 0.95$ \\
\hline
\end{tabular}

\section{DISCUSSION}

Due to the importance of the SO in sequestering anthropogenic $\mathrm{CO}_{2}$ (Sabine et al. 2004, Landschützer et al. 2015), understanding the effects of natural Fe sources under different $\mathrm{CO}_{2}$ scenarios on SO primary productivity and phytoplankton species composition can help to elucidate their combined effects on the biological carbon pump, under both present-day and future conditions. To assess their potential impacts, $\mathrm{CO}_{2}-\mathrm{Fe}$ perturbation bottle experiments with natural phytoplankton assemblages can serve as valuable tools, as they account for species interactions and reduce complexity by targeting the investigated environmental factors. These studies are, however, biased by possible bottle effects as they move the phytoplankton community from its natural environment into artificial conditions (e.g. lack of sinking and grazers larger than $200 \mu m_{i}$ Venrick et al. 1977, Calvo-Díaz et al. 2011), thereby complicating projections to the real world. Yet, to date multiple stressor experiments represent the only tool to simulate future potential climate change scenarios and their impact on future SO phytoplankton, hence these experiments can facilitate the interpretation of cause- 
effect relationships and have the potential to identify phytoplankton species in the field that could be sensitive or tolerant toward the tested climate change scenarios. Here, we present results from a bottle incubation experiment with a phytoplankton community from SO pelagic waters, elucidating the impact of different $\mathrm{Fe}$ sources (dust vs. $\mathrm{FeCl}_{3}$ ) and $p \mathrm{CO}_{2}$ levels (390 vs. $900 \mu \mathrm{atm}$ ) on Fe chemistry, POC production, and phytoplankton species composition.

The initial phytoplankton community, sampled south of the Polar Front in the Atlantic sector of the $\mathrm{SO}$, was composed of numerous diatom species and the single-celled prymnesiophyte Phaeocystis antarctica. The BSi to POC ratio was high $(0.69 \pm 0.02 \mathrm{~mol}$ $\mathrm{mol}^{-1}$; Table 5), indicating a dominance of diatoms under Fe-deficient (Trull et al. 2015; BSi:POC $\sim 0.6 \mathrm{~mol}$ $\mathrm{mol}^{-1}$ ) compared to Fe-replete (BSi:POC $\sim 0.15 \mathrm{~mol}$ $\mathrm{mol}^{-1}$ ) conditions (Hutchins \& Bruland 1998, Takeda 1998, Hoffmann et al. 2007, Assmy et al. 2013). Both the low in situ total dFe concentration $(0.23 \pm 0.06$ nmol ${ }^{-1}$; Table 1$)$ and the reduced $F_{\mathrm{v}} / F_{\mathrm{m}}(0.33 \pm 0.06$; Fig. 1) were similar to values typically observed for Fe-limited waters of the SO (Hopkinson et al. 2007, Klunder et al. 2011, de Jong et al. 2012, Trimborn et al. 2015), suggesting an Fe-limited phytoplankton assemblage at the start of the experiment. Fe fertilization was successfully achieved through addition of $0.5 \mathrm{nmol} \mathrm{l}^{-1}$ total $\mathrm{dFe}$ of dust or $\mathrm{FeCl}_{3}$, yielding similar initial total $\mathrm{dFe}$ concentrations (Table 1).

At the beginning of the first experimental phase, $F_{\mathrm{v}} / F_{\mathrm{m}}$ values increased up to $0.48 \pm 0.04$ in all treatments (Fig. $1 \mathrm{a}-\mathrm{C}$ ). This rise in $F_{\mathrm{v}} / F_{\mathrm{m}}$ was not related to total $\mathrm{dFe}$ concentrations (Table 1), but was most likely a response to the constant $30 \mu \mathrm{mol} \mathrm{m}^{-2} \mathrm{~s}^{-1}$ light supply (Feng et al. 2010). After acclimation to this irradiance, $F_{\mathrm{v}} / F_{\mathrm{m}}$ decreased to $\leq 0.2$ in all control treatments, confirming severe Fe-limitation, while $F_{\mathrm{v}} / F_{\mathrm{m}}$ of the dust and $\mathrm{FeCl}_{3}$ treatments did not fall below 0.2 until the end of the experiments (Fig. 1a-C). In line with this, nitrate concentrations were already drawn down to $10 \mu \mathrm{mol} \mathrm{l}^{-1}$ after $10 \mathrm{~d}$ or at the latest after $13 \mathrm{~d}$ in $\mathrm{FeCl}_{3}$ - and dust-enriched treatments, whereas it took $15 \mathrm{~d}$ or longer for control treatments (Fig. 1d-f), thus confirming that Fe-limitation was relieved and phytoplankton growth was stimulated through addition of either $\mathrm{FeCl}_{3}$ or dust. In fact, enrichment by dust showed similar trends in $F_{\mathrm{v}} / F_{\mathrm{m}}$ relative to $\mathrm{FeCl}_{3}$ amendment irrespective of the $p \mathrm{CO}_{2}$, suggesting that dust can successfully relieve Fe-limitation, as previously observed (Mélancon et al. 2016, Conway et al. 2016). Accordingly, total dFe concentrations increased initially after $\mathrm{Fe}$ enrichment (dust and $\mathrm{FeCl}_{3}$ ) whereas no significant differ- ences in total $\mathrm{dFe}$ were observed at the end of the first phase (Table 1). These findings further suggest that this dust was rapidly, rather than continuously, releasing Fe (Baker \& Croot 2010, Shi et al. 2011, Fishwick et al. 2014). Furthermore, similar total dFe concentrations were measured within the respective Fe treatments under both $p \mathrm{CO}_{2}$ levels (Table 1), even for the dust treatment, supporting previous observations that the effect of OA on Fe(III)' solubility is rather small in seawater over the $\mathrm{pH}$ range of 7.5 to 9 (Kuma et al. 1996, Liu \& Millero 2002, Fishwick et al. 2014). Hence, our results suggest that Fe solubility associated with dust was not significantly enhanced under OA as previously observed (Fishwick et al. 2014, Mélancon et al. 2016). Previous studies, however, reported changes in Fe(III) complexation, resulting in a decline in the bioavailability of Fe(III) to marine phytoplankton (Shi et al. 2010, Sugie et al. 2013). According to our results (derived from $\mathrm{pH} 8.1$ titrations), no changes in ligand concentrations $\left(\sum \mathrm{C}_{\mathrm{L}}\right)$ and $\mathrm{Fe}(\mathrm{III})$-ligand conditional binding affinity were detected in response to OA (Table 2). Considering, however, that variations even within the same experimental treatment for $\Sigma \mathrm{C}_{\mathrm{L}}$ were high (e.g. control 390; Table 2), further studies are required to verify this.

Even though $\mathrm{Fe}$ additions (dust or $\mathrm{FeCl}_{3}$ ) imposed strong changes in $F_{\mathrm{v}} / F_{\mathrm{m}}(\mathrm{p}<0.0001$; Fig. $1 \mathrm{a}-\mathrm{c})$, only a $\mathrm{CO}_{2}$-dependent change in the phytoplankton community structure was observed (Figs. $2 \& 3$, Tables $3 \& 4$ ). At the end of the first phase, at both $p \mathrm{CO}_{2}$ levels net growth rates were negligible for the single-celled P. antarctica (Fig. 4a), but positive for the diatom community (Fig. 4b). Such rapid growth of diatoms is commonly referred to as a boom-and-bust strategy (Smetacek et al. 2004). The difference in the phytoplankton community composition between ambient and high $p \mathrm{CO}_{2}$ mainly resulted from the absence of Pseudo-nitzschia prolongatoides under all OA treatments (Figs. 2 \& 3, Table 3), as shown by the unaltered relative contributions of Nitzschia lecointei, Chaetoceros neogracilis, Fragilariopsis curta and P. antarctica to the whole community under these conditions (see Fig. S1 in the Supplement at www.int-res.com/articles/suppl/ m578p035_supp.pdf). Such $\mathrm{CO}_{2}$ sensitivity in the genus Pseudo-nitzschia has been previously observed in bottle incubation experiments with natural phytoplankton assemblages from the Ross Sea and the Weddell Sea (Tortell et al. 2008, Hoppe et al. 2013). Similarly, growth of Pseudo-nitzschia spp. remained unaffected by OA in bottle incubation experiments with natural phytoplankton assemblages 
from the Bering Sea (Sugie et al. 2013) as well as in laboratory experiments with monocultures of the Antarctic Pseudo-nitzschia subcurvata (Trimborn et al. 2013) or the temperate Pseudo-nitzschia pseudodelicatissima (Sugie \& Yoshimura 2013). An OAdependent stimulation in growth has been reported only for temperate species such as Pseudo-nitzschia multiseries (Sun et al. 2011) and Pseudo-nitzschia fraudulenta (Tatters et al. 2012), pointing out the vulnerability of Antarctic Pseudo-nitzschia species to OA in particular.

During the second experimental phase, the similarity of the community composition for dust and $\mathrm{FeCl}_{3}$ treatments prior and after the second dilution (Table 3) suggests that a steady state situation among species was reached. During this phase, both $\mathrm{CO}_{2}$ and Fe sources were key modulators of the phytoplankton community composition. Under ambient $p \mathrm{CO}_{2}, \mathrm{FeCl}_{3}$ enrichment induced a shift within the diatom community from P. prolongatoides to N. lecointei (Figs. $2 \& 3$, Tables $3 \& 4$ ). This floristic shift in response to $\mathrm{FeCl}_{3}$ addition was further modulated by $p \mathrm{CO}_{2}$, resulting in high abundances of $C$. neogracilis under OA (Figs. 2 \& 3, Tables $3 \& 4$ ). At both $p \mathrm{CO}_{2}$ levels, diatoms became dominant following $\mathrm{FeCl}_{3}$ addition (Table 3). Such diatom-specific response to inorganic Fe enrichment has been previously reported (Tsuda et al. 2005, Boyd et al. 2007, Feng et al. 2010, Smetacek et al. 2012, Assmy et al. 2013, Hoppe et al. 2013). In both control and dust treatments, high $p \mathrm{CO}_{2}$ caused the single-celled $P$. antarctica to reach accumulation rates that were as high as those observed for the overall diatom community (Fig. $4 \mathrm{c}, \mathrm{d}$ ), resulting in it being the most abundant species in these treatments (Tables 3 \& 4).

Surprisingly, phytoplankton community composition of control and dust treatments were similar (390 treatments: $\mathrm{DI}=0.13 ; 900$ treatments: $\mathrm{DI}=0.06$ ), with $P$. prolongatoides and $P$. antarctica dominating both treatments under ambient and high $p \mathrm{CO}_{2}$, respectively (Figs. $2 \& 3$, Tables $3 \& 4$ ). This finding suggests relatively low $\mathrm{Fe}$ bioavailability for $\mathrm{Fe}$ associated with dust. When comparing the phytoplankton community composition of $\mathrm{FeCl}_{3}$ and dust treatments, our results reveal that the dominating phytoplankton species markedly differed between Fe sources (Figs. 2 \& 3 , Tables $3 \& 4$ ), under ambient $p \mathrm{CO}_{2}$ with $P$. prolongatoides and $N$. lecointei $(\mathrm{DI}=0.48)$ and under high $p \mathrm{CO}_{2}$ with $P$. antarctica and $C$. neogracilis $(\mathrm{DI}=0.30$ ) dominating the dust and $\mathrm{FeCl}_{3}$ treatments, respectively. Hence, the difference in phytoplankton community composition between dust and $\mathrm{FeCl}_{3}$ treatments suggests that in fact $\mathrm{FeCl}_{3}$ fails to mimic dust enrichments. The reason for this may potentially result from species-specific abilities to access different Fe pools (e.g. Hutchins et al. 1999, Maldonado \& Price 2001) and/or Fe bioavailability (e.g. Visser et al. 2003, Shaked et al. 2005, Morel et al. 2008, Conway et al. 2016). In response to OA, Fe uptake:POC ratios of control and dust treatments were further significantly enhanced by $127 \%$ (post hoc: $p<0.0001$ ) and $73 \%$ (post hoc: $\mathrm{p}<0.01$ ), but remained unchanged in $\mathrm{FeCl}_{3}$ treatments (Table 5), indicating higher $\mathrm{Fe}$ uptake rates by the $P$. antarctica-dominated relative to the diatom-dominated assemblage (Hassler et al. 2011, Trimborn et al. 2015). We therefore suggest that low $\mathrm{Fe}$ bioavailability in conjunction with high $p \mathrm{CO}_{2}$ may favor single-celled $P$. antarctica over diatoms.

Despite similar net daily POC production rates among all treatments at the end of the experiment (Table 5), potential changes in phytoplankton community structure can bear important implications for the marine carbon cycle. Indeed, the strength of the biological pump depends on the functional types of phytoplankton present, which act as differentially efficient vectors for vertical carbon export. $P$. antarctica, in particular as a singled-cell form, is considered to be insignificant for vertical transport of biogenic matter (Schoemann et al. 2005, Reigstad \& Wassmann 2007). Diatoms, the other dominating functional group observed here, can significantly affect carbon export depending on the degree of silicification of their frustules (Assmy et al. 2013). In line with previous findings on enhanced diatom frustule dissolution (Milligan et al. 2009) and reduced cellular BSi quotas (Sun et al. 2011, Hoppe et al. 2015, Sugie \& Yoshimura 2016) in diatoms under OA, we observed a significant OA-dependent reduction by $50 \%$ in BSi:POC ratios of both control and dust treatments ( $\mathrm{p}<0.05$; Table 5). The phytoplankton community shift towards $P$. antarctica and weakly silicified diatoms could decrease the strength of the biological pump under OA across the Fe-limited pelagic $\mathrm{SO}$, an important region accounting for $\sim 90 \%$ of the total annual primary production south of $50^{\circ}$ (Arrigo et al. 2008).

Even though multiple-stressor bottle incubation experiments are biased by possible bottle effects (artificial environment, lack of large grazers, sinking), currently they are the only tool to assess future potential climate change scenarios and their impact on future SO phytoplankton. Our results clearly support previous observations that under future increased $\mathrm{CO}_{2}$ conditions phytoplankton community structure and potential carbon export of SO high- 
nutrient, low chlorophyll (HNLC) waters can be altered (Tortell et al. 2008, Feng et al. 2010, Hoppe et al. 2013). In particular, we revealed that $\mathrm{FeCl}_{3}$, commonly used in Fe-enrichment experiments, versus more environmentally relevant Fe-laden dust enrichments, resulted in diverging effects on the dominating phytoplankton species, demonstrating that $\mathrm{FeCl}_{3}$ must be used with caution to reliably assess future phytoplankton community composition and export in an acidified pelagic SO. Although it is difficult to predict how SO phytoplankton species will respond to future climatic scenarios, it is obvious from this study that both the characterization of the phytoplankton community at the species level and the use of natural Fe sources are essential for a realistic projection of the biological carbon pump in the Fe-limited pelagic SO under OA. The results of this study furthermore highlight the need to better constrain the impact of $\mathrm{OA}$ on Fe bioavailability to SO phytoplankton species, as different Fe sources differently affect species competition, with important implications for future biological $\mathrm{CO}_{2}$ sequestration by the $\mathrm{SO}$. Moreover, multifactorial perturbation experiments need to be designed that include factors such as grazing as well as the aggregation capacity of the phytoplankton community to encompass their potential for biological carbon export, in order to fully understand the ecological responses of phytoplankton assemblages to OA in a future SO.

Acknowledgements. We thank S. Ossebar for macronutrient analysis and J. Hölscher for BSi and DIC measurements. Thanks also to H. de Baar and M. Rijkenberg who supported us in setting up the voltammetry at the AWI. We also thank F. Hinz for scanning electron microscopy pictures for identification of the species and U. Schüssler for having placed a trace metal clean container at our disposal. We gratefully thank M. Ellwood for providing the membrane pump for trace metal clean seawater sampling. Also, we thank the 3 reviewers for their detailed and helpful comments on the manuscript. Finally, we would like to thank the captain and crew of RV 'Polarstern' during ANTXXVIII/3. S.T. was funded by the Deutsche Forschungsgemeinschaft (DFG) in the framework of the priority programme 'Antarctic Research with comparative investigations in Arctic ice areas', project TR 899/2. S.T., T.B. and C.V. were funded by the Helmholtz Impulse Fond (HGF Young Investigators Group EcoTrace). C.S.H. was funded by a Swiss National Science Foundation Professor Fellowship (PP00P2_138955) and a UTS Chancellor Postdoctoral Fellowship. Furthermore, C.H. and L.N. were funded by the Australian Research Council (Discovery Project DP1092892). L.M.L. and J.S.E. participation was funded by MINECO of Spain (CGL2010-11846-E). This work was further supported by research grants from the European Research Council (ERC) under the European Community's Seventh Framework Programme (to C.J.M.H., FP7/20072013, ERC grant agreement no. 205150).

\section{LITERATURE CITED}

Arrigo KR, van Dijken GL, Bushinsky S (2008) Primary production in the Southern Ocean, 1997-2006. J Geophys Res 113:C08004

Assmy P, Smetacek V, Montresor M, Klaas C and others (2013) Thick-shelled, grazer-protected diatoms decouple ocean carbon and silicon cycles in the iron-limited Antarctic Circumpolar Current. Proc Natl Acad Sci USA 110:20633-20638

Baker AR, Croot PL (2010) Atmospheric and marine controls on aerosol iron solubility in seawater. Mar Chem 120:4-13

*Bain S, Quéguiner B, Armand L, Belviso S and others (2007) Effect of natural iron fertilization on carbon sequestration in the Southern Ocean. Nature 446:1070-1075

Boyd PW, Ellwood MJ (2010) The biogeochemical cycle of iron in the ocean. Nat Geosci 3:675-682

*Boyd PW, Jickells T, Law CS, Blain S and others (2007) Mesoscale iron enrichment experiments 1993-2005: synthesis and future directions. Science 315:612-617

Boye M, van den Berg CMG, de Jong JTM, Leach H, Croot P, de Baar HJW (2001) Organic complexation of iron in the Southern Ocean. Deep Sea Res I 48:1477-1497

Brewer PG, Bradshow AL, Williams RT (1986) Measurement of total carbon dioxide and alkalinity in the North Atlantic Ocean in 1981. In: Trabalka JR, Reichle DE (eds) The changing carbon cycle: a global analysis. Springer, New York, NY, p 358-381

Brzezinski MA, Nelson DM (1995) The annual silica cycle in the Sargasso Sea near Bermuda. Deep Sea Res I 42: 1215-1237

* Calvo-Díaz A, Díaz-Pérez L, Suárez LÁ, Morán XAG, Teira E, Marañón E (2011) Decrease in the autotrophic-toheterotrophic biomass ratio of picoplankton in oligotrophic marine waters due to bottle enclosure. Appl Environ Microbiol 77:5739-5746

Conway TM, Hoffmann LJ, Breitbarth E, Strzepek RF, Wolff EW (2016) The growth response of two diatom species to atmospheric dust from the Last Glacial Maximum. PLOS ONE 11(7):e0158553

C Croot PL, Johansson M (2000) Determination of iron speciation by cathodic stripping voltammetry in seawater using the competing ligand 2-(2-thiazolylazo)-p-cresol (TAC). Electroanalysis 12:565-576

* de Baar HJW, Gerringa LJA (2009) Effects of ocean acidification on the physical-chemical speciation of nutrients and trace metals. European Project on Ocean Acidification (EPOCA) Report. http://epoca-project.eu/

* de Jong J, Schoemann V, Lannuzel D, Croot P, de Baar H, Tison JL (2012) Natural iron fertilization of the Atlantic sector of the Southern Ocean by continental shelf sources of the Antarctic Peninsula. J Geophys Res 117:G01029

* Dickson AG, Millero FJ (1987) A comparison of the equilibrium constants for the dissociation of carbonic acid in seawater media. Deep Sea Res I 34:1733-1743

*Dourack PJ, Wijffels SE, Matear RJ (2012) Ocean salinities reveal strong global water cycle intensification during 1950 to 2000. Science 336:455-458

Edler L (1979) Recommendations on methods for marine biological studies in the Baltic Sea: phytoplankton and chlorophyll. Baltic Mar Biol Pub 5:5-38

Feng Y, Hare CE, Rose JM, Handy SM and others (2010) Interactive effects of iron, irradiance and $\mathrm{CO}_{2}$ on Ross Sea phytoplankton. Deep Sea Res I 57:368-383

FFishwick MP, Sedwick PN, Lohan MC, Worsfold PJ, Buck 
KN, Church TM, Ussher SJ (2014) The impact of changing surface ocean conditions on the dissolution of aerosol iron. Global Biogeochem Cycles 28:1235-1250

*Gerringa LJA, Herman PMJ, Poortvliet TCW (1995) Comparison of the linear van den Berg/Ruži transformation and a non-linear fit of the Langmuir isotherm applied to $\mathrm{Cu}$ speciation data in the estuarine environment. Mar Chem 48:131-142

* Gran G (1952) Determination of the equivalence point in potentiometric titration. Part II. Analyst (Lond) 77:661-671

Grasshoff K, Kremling K, Ehrhardt M (eds) (1999) Methods of seawater analysis, 3rd edn. Wiley-VCH, Weinheim

*Harris DC (1998) Nonlinear least-squares curve fitting with Microsoft Excel solver. J Chem Educ 75:119-121

*Hassler CS, Schoemann V, Nichols CM, Butler ECV, Boyd PW (2011) Saccharides enhance iron bioavailability to Southern Ocean phytoplankton. Proc Natl Acad Sci USA 108:1076-1081

Hoegh-Guldberg O, Bruno JF (2010) The impact of climate change on the world's marine ecosystems. Science 328: 1523-1528

Hoffmann LJ, Peeken I, Lochte K (2007) Effects of iron on the elemental stoichiometry during EIFEX and in the diatoms Fragilariopsis kerguelensis and Chaetoceros dichaeta. Biogeosciences 4:569-579

Hopkinson BM, Mitchell BG, Reynolds RA, Wang H and others (2007) Iron limitation across chlorophyll gradients in the southern Drake Passage: phytoplankton responses to iron addition and photosynthetic indicators of iron stress. Limnol Oceanogr 52:2540-2554

Hoppe CJM, Hassler CS, Payne CD, Tortell PD, Rost B, Trimborn S (2013) Iron limitation modulates ocean acidification effects in Southern Ocean phytoplankton communities. PLOS ONE 8:e79890

* Hoppe CJM, Holtz L, Trimborn S, Rost B (2015) Ocean acidification decreases the light use efficiency in an Antarctic diatom under dynamic but not constant light. New Phytol 207:159-171

Hutchins DA, Bruland KW (1998) Iron limited diatom growth and $\mathrm{Si}: \mathrm{N}$ uptake ratios in a coastal upwelling regime. Nature 393:561-564

* Hutchins DA, Witter AE, Butler A, Luther GW (1999) Competition among marine phytoplankton for different chelated iron species. Nature 400:858-861

IPCC (2014) Climate change 2014: synthesis report. Contribution of Working Groups I, II and III to the Fifth Assessment Report of the Intergovernmental Panel On Climate Change. IPCC, Geneva

Klunder MB, Laan P, Middag R, De Baar HJW, van Ooijen JC (2011) Dissolved iron in the Southern Ocean (Atlantic sector). Deep Sea Res II 58:2678-2694

Koroleff F (1983) Determination of silicon. In: Grasshoff K, Kremling $\mathrm{M}$ (eds) Methods of seawater analysis. WileyVCH, Weinheim, p 174-183

Kuma K, Nishioka J, Matsunaga K (1996) Controls on iron (III) hydroxide solubility in seawater: the influence of $\mathrm{pH}$ and natural organic chelators. Limnol Oceanogr 41:396-407

* Laglera LM, Santos-Echeandía J, Caprara S, Monticelli D (2013) Quantification of iron in seawater at the low picomolar range based on optimization of bromate-ammoniadihydroxynaphtalene system by catalytic adsorptive cathodic stripping voltammetry. Anal Chem 85:2486-2492

Landschützer P, Gruber N, Haumann FA, Rödenbeck C and others (2015) The reinvigoration of the Southern Ocean carbon sink. Science 349:1221-1224
Liu X, Millero FJ (2002) The solubility of iron in seawater. Mar Chem 77:43-54

Maldonado MT, Price NM (2001) Reduction and transport of organically bound iron by Thalassiosira oceanica (Bacillariophyceae). J Phycol 37:298-310

Martin JH, Gordon RM, Fitzwater SE (1990) Iron in Antarctic waters. Nature 345:156-158

* Mehrbach C, Culberson C, Hawley J, Pytkovicz R (1973) Measurement of the apparent dissociation constants of carbonic acid in seawater at atmospheric pressure. Limnol Oceanogr 18:897-907

* Mélancon J, Levasseur M, Lizotte M, Scarratt M and others (2016) Effects of dust additions on phytoplankton growth and DMS production in high $\mathrm{CO}_{2}$ northeast Pacific HNLC waters. Biogeosciences 13:1677-1692

Millero FJ, Woosley R, DiTrolio B, Waters J (2009) Effect of ocean acidification on the speciation of metals in seawater. Oceanography (Wash DC) 22:72-85

Milligan AJ, Mioni CE, Morel FMM (2009) Response of cell surface $\mathrm{pH}$ to $\mathrm{pCO}_{2}$ and iron limitation in the marine diatom Thalassiosira weissflogii. Mar Chem 114:31-36

Moore JK, Braucher O (2008) Sedimentary and mineral dust sources of dissolved iron to the world ocean. Biogeosciences 5:631-656

* Morel FMM, Kutska AB, Shaked Y (2008) The role of unchelated $\mathrm{Fe}$ in the iron nutrition of phytoplankton. Limnol Oceanogr 53:400-404

Pierrot DE, Lewis E, Wallace DWR (2006) MS Excel program developed for $\mathrm{CO}_{2}$ system calculations. Carbon Dioxide Information Analysis Center, Oak Ridge National Laboratory, Oak Ridge, TN

* Reigstad M, Wassmann P (2007) Does Phaeocystis spp. contribute significantly to vertical export of biogenic matter? Biogeochemistry 83:217-234

* Sabine CL, Feely RA, Gruber N, Key RM and others (2004) The oceanic sink for anthropogenic $\mathrm{CO}_{2}$. Science 305: 367-371

Schoemann V, Becquevort S, Stefels J, Rousseau V, Lancelot C (2005) Phaeocystis blooms in the global ocean and their controlling mechanisms: a review. J Sea Res 53:43-66

* Shaked Y, Kutska AB, Morel FMM (2005) A general kinetic model for iron acquisition by eukaryotic phytoplankton. Limnol Oceanogr 50:872-882

Shi D, Xu Y, Hopkinson BM, Morel FMM (2010) Effect of ocean acidification on iron availability to marine phytoplankton. Science 327:676-679

* Shi Z, Bonneville S, Krom MD, Carslaw KS, Jickells TD, Baker AR, Benning LG (2011) Iron dissolution kinetics of mineral dust at low $\mathrm{pH}$ during simulated atmospheric processing. Atmos Chem Phys 11:995-1007

* Sigman DM, Boyle EA (2000) Glacial/interglacial variations in atmospheric carbon dioxide. Nature 407:859-869

* Smetacek V, Naqvi SWA (2008) The next generation of iron fertilization experiments in the Southern Ocean. Phil Trans R Soc A 366:3947-3967

* Smetacek V, Assmy P, Henjes J (2004) The role of grazing in structuring Southern Ocean pelagic ecosystems and biogeochemical cycles. Antarct Sci 16:541-558

Smetacek V, Klaas C, Strass VH, Assmy P and others (2012) Deep carbon export from a Southern Ocean iron-fertilized diatom bloom. Nature 487:313-319

Sugie K, Yoshimura T (2013) Effects of $p \mathrm{CO}_{2}$ and iron on the elemental composition and cell geometry of the marine diatom Pseudo-nitzschia pseudodelicatissima (Bacillariophyceae). J Phycol 49:475-488 
Sugie K, Yoshimura T (2016) Effects of high $\mathrm{CO}_{2}$ levels on the ecophysiology of the diatom Thalassiosira weissflogii differ depending on the iron nutritional status. ICES J Mar Sci 73:680-692

Sugie K, Endo H, Suzuki K, Nishioka J, Kiyosawa H, Yoshimura T (2013) Synergistic effects of $p \mathrm{CO}_{2}$ and iron availability on nutrient consumption ratio of the Bering Sea phytoplankton community. Biogeosciences 10:6309-6321

Sun J, Hutchins DA, Feng Y, Seubert EL, Caron DA, Fu FX (2011) Effects of changing $p \mathrm{CO}_{2}$ and phosphate availability on domoic acid production and physiology of the marine harmful bloom diatom Pseudo-nitzschia multiseries. Limnol Oceanogr 56:829-840

Takeda S (1998) Influence of iron availability on nutrient consumption ratio of diatoms in oceanic waters. Nature 393:774-777

Tatters AO, Fu FX, Hutchins DA (2012) High $\mathrm{CO}_{2}$ and silicate limitation synergistically increase the toxicity of Pseudo-nitzschia fraudulenta. PLOS ONE 7:e32116

Tomas CR (ed) (1997) Identifying marine phytoplankton. Academic Press, New York, NY

Tortell PD, Payne CD, Li Y, Trimborn S and others (2008) $\mathrm{CO}_{2}$ sensitivity of Southern Ocean phytoplankton. Geophys Res Lett 35:L04605

Trimborn S, Brenneis T, Sweet E, Rost B (2013) Sensitivity of Antarctic phytoplankton species to ocean acidification: growth, carbon acquisition and species interaction. Limnol Oceanogr 58:997-1007

Editorial responsibility: Katherine Richardson, Copenhagen, Denmark
Trimborn S, Hoppe CJM, Taylor B, Bracher A, Hassler C (2015) Physiological characteristics of phytoplankton communities of Western Antarctic Peninsula and Drake Passage waters. Deep Sea Res I 98:115-124

*Trull TW, Davies DM, Dehairs F, Cavagna AJ and others (2015) Chemometric perspectives on plankton community responses to natural iron fertilisation over and downstream of the Kerguelen Plateau in the Southern Ocean. Biogeosciences 12:1029-1056

Tsuda A, Takeda S, Saito H, Nishioka J and others (2005) Response of diatoms to iron-enrichment (SEEDS) in the western subarctic Pacific, temporal and spatial comparisons. Prog Oceanogr 64:189-205

Utermöhl H (1958) Zur Vervollkommnung der quantitativen Phytoplankton-Methodik. Mitt Int Verein theor angew Limnol 9:1-38

* van den Berg CMG (1982) Determination of copper complexation with natural organic ligands in seawater by equilibration with $\mathrm{MnO}_{2}$ I. Theory. Mar Chem 11:307-322

* Venrick EL, Beers JR, Heinbokel JF (1977) Possible consequences of containing microplankton for physiological rate measurements. J Exp Mar Biol Ecol 26:55-76

*Visser F, Gerringa LJA, Van der Gaast SJ, de Baar HJW, Timmermans KR (2003) The role of the reactivity and content of iron of aerosol dust on growth rates of two Antarctic diatom species. J Phycol 39:1085-1094

Zuur AF, Ieno EN, Smith GM (2007) Analysing ecological data. Springer Science + Business Media, New York, NY

Submitted: October 5, 2016; Accepted: July 3, 2017

Proofs received from author(s): August 4, 2017 